Jahrbuch für Geschichte Lateinamerikas

Anuario de Historia de América Latina

$57|2020| 255-293$

Magdalena Chocano

Universidad Nacional Federico Villarreal, Lima

Incredulidad y disidencia religiosa en el Perú de entresiglos, 1880-1904
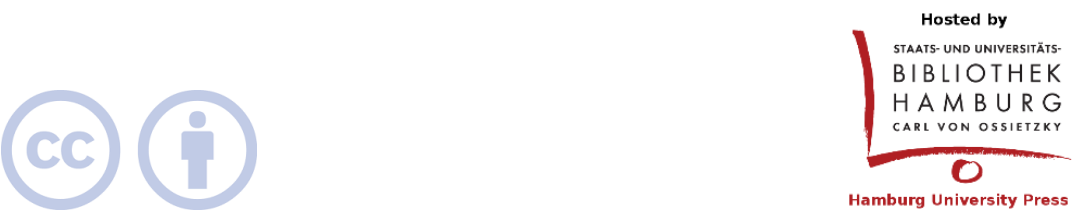

Except where otherwise noted, this article is licensed under a

Creative Commons Attribution 4.0 International license (CC BY 4.0)

https://doi.org/10.15460/jbla.57.195 


\title{
Incredulidad y disidencia religiosa en el Perú de entresiglos, 1880-1904
}

\author{
Magdalena Chocano ${ }^{1}$
}

\begin{abstract}
In Peru, after the defeat in the war with Chile, religious unity embodied by Catholicism was considered by the elites as the only factor granting national unity in a ruined country with weakened institutions. This approach did not succeed in eliminating the manifestations of scepticism or different beliefs, such as deism, freethinking and spiritualism, by individuals or groups that, despite being a minority, had a significant public profile. This article examines the debates of the freemasons and freethinkers, as well as the activities of other dissidents, in order to offer a more complex portrait of the history of the circulation of ideas in Republican Peru.
\end{abstract}

Keywords: Liberalism, Atheism, Freethinking, Freemasonry, Spiritualism.

Resumen. - En el Perú de la posguerra con Chile, la unidad religiosa encarnada por el catolicismo pareció a las elites una garantía de unidad, dado el estado de ruina generalizada y el resquebrajamiento de las instituciones. Este planteamiento no logró eliminar las manifestaciones de incredulidad ni de creencias diferentes, tales como el deísmo, el libre pensamiento o el espiritismo, por parte de individuos o grupos que aunque minoritarios tuvieron un perfil público significativo. Examinamos los debates de los masones y los librepensadores, así como las actividades de otros disidentes, para ofrecer elementos que contribuyan a trazar un panorama más complejo de la historia de la circulación de ideas en el Perú republicano.

Palabras clave: liberalismo, ateísmo, librepensamiento, masonería, espiritismo.

En el orden republicano que se fue construyendo trabajosamente desde 1821 se concebía la unanimidad religiosa como única forma de pertenencia a la nación; esta visión se trasladó a la constitución que en

1 Este trabajo fue presentado en una sesión del Taller Porras, de la Universidad Nacional Mayor de San Marcos, a cargo del profesor Cristóbal Aljovín. La autora agradece las sugerencias de los historiadores Fernando Armas Asín, Guillermo Nugent y María Emma Mannarelli, y las de los asistentes a dicho evento. 
su artículo $4^{\circ}$ señalaba que la religión católica era la única del Estado, y prohibía todo culto diferente. ${ }^{2}$ Por tanto peruanidad se identificaba con catolicidad, y cualquier manifestación pública distinta a las creencias y costumbres fomentadas por el clero católico estaba sujeta a una sanción penal que debía ejercer el Estado al ser el garante del exclusivismo religioso. Se conformaba así una esfera pública como indicio presuntamente de una sociedad democrática, con la salvedad de que la Iglesia católica dominaba las manifestaciones colectivas, incluso las civiles. $^{3}$

Los sectores liberales luchaban por eliminar el requisito de adhesión al catolicismo para ser considerado ciudadano peruano y así favorecer la inmigración extranjera, a la que veían como ingrediente necesario para el progreso de la nación peruana. Mientras la lucha liberal por abolir el tributo indígena, la esclavitud y las restricciones a la circulación interna se inspiraban directamente en las necesidades de los

2 Con variantes esta disposición apareció en las constituciones de 1823 (art. 8o),

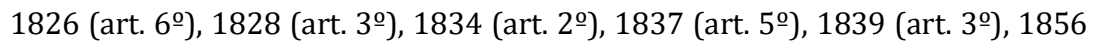
(art. $4^{\circ}$ ), 1860 (art. $4^{\circ}$ ), 1867 (art. 3ํㅜ), 1920 (art. 5ํㅜ). Aun con la aceptación de la predicación pública de otras confesiones, el Estado privilegió a la Iglesia católica con su protección en la constitución de 1933: “Artículo 232.- Respetando los sentimientos de la mayoría nacional, el Estado protege la Religión Católica, Apostólica y Romana. Las demás religiones gozan de libertad para el ejercicio de sus respectivos cultos", en línea: http://www4.congreso.gob.pe/historico/ quipu/constitu/1933.htm [19-11-2020]. Esta idea que liga nación y religión sería reforzada en el siglo XX por la ideología de la "peruanidad" tal como fue formulada por Víctor Andrés Belaúnde, filósofo y militante del Partido Demócrata. Sobre los antecedentes ideológicos de la vinculación entre integración nacional y unidad religiosa, véase Pilar García Jordán, Iglesia y poder en el Perú contemporáneo. 1821-1919, Cusco: Centro de Estudios regionales Andinos Bartolomé de las Casas, 1991, pp. 53-58 y Fernando Armas Asín, Liberales, protestantes y masones. Modernidad y tolerancia religiosa. Perú. Siglo XIX, Lima: Fondo Editorial PUCP / Centro de Estudios regionales Andinos Bartolomé de las Casas, 1998, pp. 205-229.

3 El caso más conocido es el del predicador metodista Penzotti que fue encarcelado preventivamente por presión del arzobispo de Lima unos meses de 25 de julio de 1890 a 28 de marzo de 1891 por infracción del art. 4ํ de la constitución. La presión de los liberales y de diversos consulados extranjeros lograron su liberación, Jeffrey L. Klaiber, La Iglesia en el Perú. Su historia social desde la independencia, Lima: Fondo Editorial PUCP, 1996, pp. 138-139; García Jordán, Iglesia y poder, pp. 244-245; Armas Asín, Liberales, protestantes y masones, pp. $152-170$. 
habitantes del país, el logro de la tolerancia religiosa parecía en cierto sentido una demanda ajena a estos. Esto ha gravitado en la visión historiográfica del liberalismo que ya es considerado como fenómeno doctrinario (Basadre) o limitado simplemente a la idea de libre comercio (Yépez). ${ }^{4}$ El clero católico y sus feligreses probablemente lo veían así: una vida cotidiana y festiva marcada por el calendario religioso y por compromisos personales establecidos mediante el ritual católico, resultaban impermeable a una propuesta que precisamente implicaba modificar la organización institucional instaurando, por ejemplo, el registro civil de hechos vitales (nacimiento, matrimonio, fallecimiento), o una educación laica. De modo que las demandas de derechos civiles que tuvieran que ver con la esfera 'cultural' (por llamarla así) no era 'popular', y se situaba más bien dentro de un planteamiento general sobre el progreso y de las ideas civilizatorias propias del liberalismo.

En este trabajo se trata de seguir el rastro de las concepciones que desafiaron la unanimidad religiosa del país desde una clara posición de minoría, lo cual conllevaba ciertas ambigüedades y un terreno poco firme para asentarse. Desde ese punto de vista examinaremos ámbitos como los debates masónicos y de otros disidentes tras la guerra con Chile, momento en que la unidad religiosa encarnada por el catolicismo pareció a las elites una garantía de unidad nacional dado el estado de ruina generalizada del país y el resquebrajamiento de las instituciones existentes. El límite temporal de este examen es 1904 porque en esa fecha cesó de publicarse El Libre Pensamiento, el único periódico dedicado exclusivamente a fomentar la postura librepensadora en el medio limeño. Destacamos la influencia de las corrientes disidentes en fomentar cambios en el panorama religioso del país al abrir la posibilidad de explorar diversas nociones y experiencias religiosas e incluso de asumir una actitud de incredulidad, y haremos observaciones sobre sus alcances.

\footnotetext{
4 Por ejemplo, Jorge Basadre, Perú. Problema y posibilidad, Lima: Editorial Rosay, 1931, pp. 54-105, habla de "ciclos doctrinarios" o, en Jorge Basadre, Historia de la república del Perú, Lima: Editorial Universitaria, 1969, vol. 2, p. 62, de hombres “doctrinarios". Ernesto Yépez del Castillo, Perú. 1820-1920. Un siglo de desarrollo capitalista, Lima: Instituto de Estudios Peruanos / Campodónico Ediciones, 1972, pp. 95-103, presenta las ideas sobre gestión económica del presidente Manuel Pardo (1834-1878) como expresión de un "profundo liberalismo".
} 


\section{La masonería peruana entre el deísmo y el cientificismo}

En 1882, en plena ocupación chilena de Lima, los "masones ilustrados y liberales" organizaron la Gran Logia del Perú (GLP). ${ }^{5}$ Al iniciarse en las logias de la GLP los adeptos debían suscribir el principio básico de la constitución masónica:

"La Gran Logia de los Antiguos, Libres y Aceptados Masones de la República del Perú, reconoce y proclama la existencia de Dios y la inmortalidad del alma, y exige esta declaración de principios a todos sus miembros y candidatos para la iniciación".6

Pese a ello a algunos masones les preocupaba que en su organización se pudiera llegar a cuestionar la idea de la existencia de Dios (el Gran Arquitecto del Universo o G.. A. $\cdot$ D. $\therefore$ U. .). Así un hermano bajo el alias 'Guillermo Tell', escribía críticamente:

"La Mas[onería] francesa ha querido dar un paso adelante, permitiendo que en su seno se recibiesen también personas que niegan la existencia de Dios y la inmortalidad del alma, sin considerar que obrando de esta manera pierden el derecho al título de mas[ones] [...]".?

Insistía en que se mantuvieran las tres preguntas del rito escocés a los neófitos: si cree en Dios, en la justicia divina y en la vida futura, ya que, a su entender, eran rasgos fundamentales del espiritualismo masónico. De manera que la tolerancia que proponía la masonería y que llevó a sus

5 "La reforma": Revista Masónica [RM], no 1, 15 de febrero de 1882, p. 2. La Gran Logia del Perú [GLP] fue expresión de la nacionalización organizativa de la masonería en el Perú, tema que he abordado en un trabajo anterior: Magdalena Chocano, "Lima masónica. Las logias simbólicas y su progreso en el medio urbano peruano de fines del siglo XIX": Revista de Indias, 249 (2010), pp. 409-444.

6 "Constitución de la Gran Logia de los Antiguos, Libres y Aceptados Masones de la República del Perú”: RM, no 4, 1 de abril de 1882, p. 21; también Gran Logia del Perú, constitución, estatutos, reglas de orden, antiguos linderos y antiguos cargos, Lima: Carlos Prince, 1888, p. 5. Sobre la organización de la GLP en la posguerra con Chile véase Chocano, "Lima masónica", pp. 409-444. Algunos aspectos de la masonería republicana antes y después de la guerra se estudian en María Inés Valdivia, El liberalismo social en el Perú. Masones, bomberos, librepensadores y anarquistas durante el siglo XIX, Lima: Asamblea Nacional de Rectores, 2010, pp. 43-66, 92-103.

${ }^{7}$ Guillermo Tell, "El título preliminar de la constitución de la Gr.. Log. .": RM, no 7, 1 de mayo de 1882, p. 42. 
miembros a luchar contra el artículo $4^{\circ}$ de la constitución del país, tendía a excluir a los que cuestionaran la religión como tal.

Esto probablemente se debió al temor de verse asociados con el ateísmo y sufrir por ello el aislamiento social, cosa indeseable pues precisamente uno de los valores de la masonería era el fomento de una sociabilidad laica. Ya antes de la guerra, el sacerdote Manuel Tovar (1844-1904), subdecano de la Facultad de Teología de la Universidad de San Marcos, en su discurso de apertura del año académico de 1877, sindicaba a la Franc-Masonería como escuela racionalista que negaba lo sobrenatural, y ende al ser supremo, y dedicaba su vasta asociación extendida por todo el mundo a propagar el ateísmo. Aunque indicaba que no sabía si había "verdaderos ateos", 8 Tovar procuró relacionar con el ateísmo los esfuerzos por establecer la educación laica, el matrimonio civil y los cementerios públicos, y aducía como prueba los pronunciamientos de logias de habla francesa que negaban todo principio de autoridad sobrenatural. Se congratulaba Tovar de que en San Marcos se mantuviera la ortodoxia católica y de que en el país no se hubiera presentado una amenaza racionalista inminente. ${ }^{9} \mathrm{El}$ control de la Iglesia sobre la opinión se evidencia en que un libro cuestionador de la religión como Los dogmas fundamentales del catolicismo ante la razón (Valparaíso, 1873) de Mariano Amézaga se haya debido publicar fuera del país, o al menos así consta en el pie de imprenta, ya que según la ley de imprenta todo escrito que tuviera temas religiosos debía contar con la aprobación eclesiástica. ${ }^{10}$

Aunque Tovar enunciara sus acusaciones de forma poco directa, lo cierto es que en el medio masónico limeño sí se manifestó la incredulidad. Ya el 20 de mayo de 1878 en una tenida de la logia Partenón № 7, el hermano Romería dio un discurso criticando al h.

8 "Discurso Pronunciado por el Sub-Decano de la Facultad de Teología, canónigo Dr. D. Manuel Tovar, en la ceremonia de apertura del año escolar de 1877": Anales Universitarios del Perú, 1877, vol. 10, pp. 3-21. Cita en p. 7.

${ }^{9}$ Ibid., p. 18.

10 El autor Mariano Amézaga antes había publicado 'Refutación de una doctrina' (Lima, 1871) cuestionando que se marginara de la carrera eclesiástica a los hijos "adulterinos". El texto fue después publicado en folletín por El Libre Pensamiento $[E L P]$ desde el no 182, 18 de noviembre de 1899 hasta inicios de 1900. Esta autorización eclesiástica para libros que trataran temas religiosos fue establecida por la ley de imprenta de 1823, Armas Asín, Liberales, protestantes y masones, pp. 36-37. 
Jordan por utilizar "el manto fascinador de la libertad de conciencia"11 para negar implícitamente a Dios y la inmortalidad del alma. Se alarmaba Romería de que esto pudiera abrir la puerta al ateísmo ("ese monstruo que quiere devorar las sociedades"), al materialismo y a la "incredulidad sistemada",12 lo que haría peligrar los fundamentos morales de la vida social, ya que sin Dios consideraba que estos no podían existir. Al igual que algunos masones Romería pensaba que el catolicismo era una secta, pero censuraba a Jordan por proponer la eliminación de todos los cultos externos. Insistía Romería en que la idea de Dios era innata en el hombre y que había ido evolucionando de la idolatría al cristianismo, por mucho que este hubiera sido pervertido por la Iglesia. Aseguraba Romería que la masonería filosófica se basaba en el dogma espiritualista de la existencia de Dios y que por eso había podido admitir a todas las religiones. ${ }^{13}$ Es probable que fuera el primer debate sobre el ateísmo ocurrido en el país. Lamentablemente el discurso del $h . \cdot$ Jordan no parece haber sido publicado, y no podemos conocer de primera mano su argumentación.

La preocupación por el dilema entre religión e irreligión, si bien no era generalizada, sí había ya aflorado en el ámbito académico de manera atenuada, pues aunque se hacía referencia a la inexistencia de Dios, se optaba por adherirse a la ortodoxia creyente. Así, T. Whilar, quien corriendo los años fundaría una escuela de educación secundaria, presentó una tesis para optar al grado de Bachiller en la Universidad Mayor de San Marcos en 1879, titulada 'Consideraciones Filosóficas sobre el atomismo' en que demostraba que la ciencia no llevaba a desconocer la existencia de un dios creador, y criticaba con firmeza a Baruch Spinoza por haber sido un promotor del ateísmo. ${ }^{14}$ Es decir ya antes de la guerra de 1879 , se había presentado la necesidad de atajar cualquier vía que pudiera desembocar en una divulgación de una concepción atea del mundo.

Después de la guerra, insistiendo en la necesidad de impedir que el ateísmo penetrara en la institución masónica, Pedro M. Barrós (su

11 "Material leído por H. $\cdot$ Romería en la ten. $\bullet$ ord. $\cdot$ que celebró el Tall.. Partenón N. 7 el 20 de mayo de 1878, E. . V.:": RM, no 2, 1 de marzo de 1882, pp. 3-4.

12 Ibid.

13 Ibid.

14 Agustín T. Whilar, Consideraciones filosóficas sobre el atomismo, Lima: Universidad Mayor de San Marcos, Facultad de Letras, 1879 (tesis de bachiller). 
nombre masónico fue Rosbar), venerable de la logia Regeneración Fraternal № 9, publicó un artículo titulado 'El primer dogma de la Masonería Universal es la creencia en Dios y ningún ateo puede ser masón' en que se esforzaba por refutar las acusaciones de Tovar, pues estimaba que este simplemente buscaba profundizar la ignorancia sobre el tema para mantener la preeminencia del clero. Sostenía Barrós que filósofos de la corriente ilustrada y liberal como Rousseau, Leibniz y Lammenais habían defendido la existencia de Dios, pero que estaban contra la intolerancia, el fanatismo, la tiranía y el llamado jesuitismo (una especie de hipocresía religiosa atribuida a los jesuitas), y por tanto a los masones les correspondía mantener la misma actitud. ${ }^{15}$

En la memoria de 1882 de la activa logia Alianza y Firmeza № 6, que reclutaba sobre todo a estudiantes universitarios, el Venerable indica que varios solicitantes declararon tener por religión el deísmo, lo cual motivó una consulta con la GLP para superar "infundados temores" que pudieran surgir en las demás logias preocupadas ya desde antes de la guerra por la acusación de ateísmo que pesaba sobre sus miembros. ${ }^{16}$ El deísmo dentro de las filas masónicas era pues defendido y hasta fomentado, mientras se buscaba mantener a distancia a los elusivos ateos limeños. Christian Dam (cuyo alias masónico era Demóstenes), de la dirección colegiada de la Revista Masónica $(R M)$ y hermano de la logia Orden y Libertad № 2, publicó una traducción de los 'linderos' (landmarks) de la orden masónica, uno de los cuales, el 19o- subrayaba que no había en los anales de la orden antecedente alguno de un ateo declarado que se hubiera hecho masón. El lindero $20^{\circ}$ enunciaba que el masón debía creer en la resurrección a una vida futura. Asimismo, el lindero $21^{\circ}$ indicaba que en los altares de las logias debía haber "un libro de la ley"; esta disposición se prestará a interpretaciones que llegarían a motivar un serio conflicto en la GLP, como veremos. ${ }^{17}$

Dentro del deísmo puede ubicarse a Gerardo Cabello, hermano de la novelista Mercedes Cabello de Carbonera (1842-1909), y miembro de

\footnotetext{
15 "Material leído por el h. $\because$ P. M. $\cdot$ B. $\cdot$ g. $\cdot 3 . \cdot$ en ten. $\cdot$ ord. $\cdot$ del jueves 7 de agosto de 1882": RM, no 1,1 de octubre de 1882, pp. 27-34.

$16 \mathrm{RM}, \mathrm{n}$ - 14, 21-29, 11 de enero de 1883 p. 26.

17 Christian Dam (Demóstenes), “Los fundamentos de la ley masónica”: RM, no 8, 15 de mayo de 1882, pp. 46-47.
} 
la logia Honor y Progreso № 479,18 quien afirmaba que el sentimiento religioso era un fenómeno espontáneo, que debía ser regulado por la racionalidad, para evitar el predominio de la clase sacerdotal que históricamente había procurado dejar al pueblo en la ignorancia. Pasaba a demostrar el control que dicha clase había ejercido en la vida social de la India y de Grecia. En esta última el progreso de la filosofía había limitado hasta cierto punto la injerencia sacerdotal. Analizaba asimismo el estado de la predicación católica, criticando el que los sermones estuviesen llenos de amenazas en vez de exponer razonadamente las reglas para alcanzar la virtud, por ese motivo creía que el clero no estaba cumpliendo con su deber educacional. Sustentaba que debía existir una escuela liberal que pudiera combatir al seminario católico en un clima de derechos, por esto cuestionó que el Estado favoreciera dichos seminarios en detrimento de los colegios. También criticó la orientación quietista y mística de los conventos, y consideró que los únicos institutos religiosos realmente útiles eran los de misioneros y de hermanas de la caridad por su orientación práctica. De estos conceptos colegía que la misión de la masonería era desterrar la idea de infalibilidad del clero y la preponderancia del culto externo. Más aún aquella debía ser el baluarte de la libertad de conciencia expresada en la libertad de cultos, de enseñanza, de libertad política que combatiera a la "hidra de la ignorancia y el fanatismo".19

En su siguiente colaboración, titulada 'Libertad religiosa', Gerardo Cabello señala que el culto es la prueba de la fe, pero como hay muchos cultos, el ideal de una unidad religiosa para la humanidad es un fin inalcanzable. Dice: "el derecho de adorar a la Divinidad se funda en el

18 Esta logia se adhirió a la GLP con el no 5 del rol en junio de 1882. Cabello tenía el cargo de 1 vigilante. Era abogado pero parece que no tuvo mayor éxito en su profesión, Ismael Pinto Vargas, Sin perdón y sin olvido. Mercedes Cabello de Carbonera y su mundo, Lima: Universidad San Martín de Porres, 2003, pp. 255256. Por encargo del Congreso Masónico, celebrado en abril de 1882, Cabello integró con otros dos masones una comisión para estudiar la factibilidad de fundar un colegio patrocinado por la GLP, RM, no 7, 1 de mayo de 1882, p. 42. Había experiencias previas protagonizadas por la logia Paz y progreso, pero consideraban que no se habían podido consolidar por la falta de un organismo masónico unificado como la GLP. Sección Crónica, RM, no 3, 15 de marzo de 1882, p. 19.

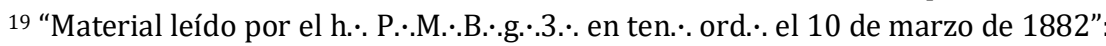
RM, no 3, 15 de marzo de 1882, p. 20; no 4, 1 de abril de 1882, pp. 27-28; no 5, 15 de abril de 1882, p. 32; no 6 [extraordinario], 23 de abril de 1882, p. 34. 
libre albedrío, es decir, en la expontánea adhesión de la conciencia a una verdad que representa el ideal religioso". ${ }^{20}$ Pero dentro de estos cultos, el catolicismo es "la religión más perfecta y progresiva",21 aunque con un número de fieles inferior al del budismo, religión que estima falsa y retrógrada, sin mayor explicación. De todos modos, considera que la era de las guerras de religión es una cosa del pasado, y se expresa contra el artículo $4^{\circ}$ de la constitución peruana pues limita la libertad de cultos. No niega la religión, ni acepta que sea posible profesar el ateísmo; espera, eso sí, que en la religión se dé prioridad a la razón, dejando de lado la exaltación de la imaginación y del sentimiento. ${ }^{22}$

Al parecer, Gerardo Cabello estuvo muy interesado también en la teosofía, en contraste con su célebre hermana, Mercedes, que se orientó al positivismo. ${ }^{23}$ Este interés de Gerardo Cabello no necesariamente se oponía al racionalismo masónico, el cual se podía aplicar sin problema al ámbito de lo mítico y lo simbólico. Así en la revista de la orden masónica se publicaron diversos artículos de corte numerológico y esotérico, por ejemplo: 'El número tres' que es un extracto de Ortodoxie maçonnique, autor era llamado el "más sabio de los masones franceses", esto es Jean Marie Ragon (1781-1862), con el objeto de que fuera utilizado en tenidas de instrucción de las logias.24 También es demostrativo que el $h$. . Federico Ego-Aguirre, secretario de Alianza y

20 "Libertad religiosa": RM, no 7, 1 de mayo de 1882, p. 41.

21 Ibid.

22 Ibid.

23 Pinto, Sin perdón y sin olvido, p. 103. Pinto caracteriza a Mercedes Cabello como "seguidora de la religión de la humanidad", pero esto es dudoso puesto que ella escribió: Cabello, La religión de la humanidad, Lima: Imprenta de Torres Aguirre, 1894, en respuesta al escritor chileno Juan Enrique Lagarrigue, Carta sobre la religión de la Humanidad dirigida a la señora doña Mercedes Cabello de Carbonera, Santiago de Chile: Cervantes, 1892, marcando distancia de dicho sistema de creencias por el lugar restringido al ámbito doméstico que asignaba a las mujeres y por considerar que solo correspondía a un momento histórico. Véase Isabelle Tauzin-Castellanos, "El positivismo peruano en versión femenina. Mercedes Cabello de Carbonera y Margarita Práxedes Muñoz": Boletín de la Academia Peruana de la Lengua, 27 (1996), pp. 79-100.

24 "El número tres": RM, no 3, 15 de marzo de 1882, pp. 19-18. Artículos análogos son Ragón, "El número 5": RM, no 6, 23 de abril de 1882, p. 35; "El número 7": nº 7, 11 de mayo de 1882, pp. 42-43. También Romería, "El círculo": RM, no 6, 23 de abril de 1882, p. 23. 
Firmeza № 6, llevara como alias masónico 'Kardec' en honor al célebre espiritista francés Alan Kardec (1804-1869), cuyo verdadero nombre era Hippolyte Léon Denizard Rivail. Un librepensador como Rada y Paz Soldán era también un firme creyente en entidades incorpóreas que se manifestaban en la vida cotidiana (las llamadas 'ánimas' o 'penas' en el medio limeño).25

La historia de las religiones y del origen del simbolismo masónico interesaba vivamente a los masones y su estudio abría vías no siempre compatibles con el entorno. En una tenida de instrucción (una sesión sobre temas masónicos) el 22 de junio de 1882 en la logia Orden y Libertad № 2, Christian Dam cuestionó el origen bíblico del simbolismo masónico. No conocemos más del contenido de su intervención, salvo que se fundó en autores respetados de la literatura masónica. ${ }^{26}$ En la tenida de 15 de junio de 1882 de Alianza y Firmeza № 6, un hermano con el alias masónico de 'Igualdad' leyó un trabajo titulado 'El deísmo'. ${ }^{27}$ De un interés especial es que Eduardo Lavergne, director de la $R M$, amigo íntimo de Manuel González Prada, ${ }^{28}$ se distanciara de cualquier asomo de incredulidad, pues recalcaba que la

"masonería reconoce una teogonía derivada de la necesidad de un Ser Supremo como causa indispensable de la creación, y no como efecto del temor que la débil

25 Adriana (de Verneuil, de solteira) de González Prada, Mi Manuel, Lima: Editorial Antártica, 1945, pp. 357-358. También fue espiritista su pariente Carlos Paz Soldán, véase más adelante en el acápite sobre espiritismo.

26 "Crónica": RM, no 9, 15 de julio de 1882, inserta en La Patria, 28 de julio de 1882.

27 “Crónica Masónica”: RM, no 9, 15 de julio de 1882, inserta en La Patria, 28 de julio de 1882.

28 Es oportuno mencionar que Eduardo Lavergne fue nombrado 2o vicepresidente del comité central directivo de la Unión Nacional, partido que fundó junto con Manuel González Prada, quien ocupó el cargo de presidente, en mayo de 1891, "La Unión Nacional": La Integridad, no 106, 1 de agosto de 1891, p. 2. Su amistad con González Prada databa de la guerra con Chile, en que estuvieron juntos en las baterías del cerro del Pino, cerca de Lima. Lavergne también fue testigo de su matrimonio con Adriana de Verneuil, y ella da fe de la íntima amistad de Prada y Lavergne pues aquel lo recibía el 1 de enero, haciendo una excepción pues evitaba recibir visitas ese día, González Prada, Mi Manuel, pp. 132 y 394. 
humanidad esperimenta [sic] al observar las leyes que presiden al movimiento de la materia en sus múltiples transformaciones". ${ }^{29}$

Considera que la ciencia colabora con la masonería al ser esta una "religión de las reflexiones", 30 con lo que trata de establecer una alianza entre esta y el pensamiento científico. Esta apertura o síntesis entre fe y ciencia permite a Lavergne incorporar la noción de progreso alineada con la de perfectibilidad de "toda la naturaleza". ${ }^{11}$ Desde ese punto de vista, no especialmente original, describe la evolución de las religiones: el temor habría llevado a los seres humanos primitivos a atribuir divinidad a múltiples fuerzas naturales, la iluminación paulatina del cerebro humano por "el dogma de la existencia del alma" hizo a los hombres ver "más allá de la materia" y dio origen a la creencia en un Dios espiritual e incorpóreo que reemplazó las creencias primitivas. En esta evolución la masonería es "fe fundada en la ciencia", "encarnación del progreso", y como tal elemento de adelanto para las sociedades. ${ }^{32}$

Lavergne examina los orígenes de la religión masónica en sus 'Estudios históricos sobre la Masonería', en que se refiere a los presuntos orígenes de sus símbolos en la India. Atribuye un simbolismo proto-masónico al budismo, sistema religioso enfrentado a la teocracia hinduista. Sin una ligazón muy clara, afirma que este simbolismo habría renacido en Persia con Zoroastro, quien habría promovido uno de los valores masónicos: la fraternidad. De Persia la doctrina francmasónica habría pasado a Egipto, donde se plasmó en la mitología de Osiris, cuyas leyendas - dice - influyen en el ceremonial masónico utilizado en el momento. Por fin, señala, se cristaliza la doctrina de un dios único en Moisés, y desaparece en Israel el gobierno de los sacerdotes y domina la personalidad de Salomón. ${ }^{33}$ Lavergne sostiene que la sociabilidad es

29 “Crónica": RM, no 9, 17 de julio de 1882, s. p., inserta en La Patria, 28 de julio de 1882 (discurso en tenida de iniciación del médico J. B. en la logia Orden y Libertad № 2).

30 Ibid.

31 Ibid.

32 "Crónica": RM, no 9, 17 de julio de 1882, s. p., inserta en La Patria, 28 de julio de 1882 (discurso en tenida de iniciación del médico J. B. en la logia Orden y Libertad № 2).

33 "Estudios históricos sobre la Masonería": Revista Masónica del Perú [RMP], no 147, 31 de enero de 1894, pp. 1-8; no 148, 28 de febrero de 1894, pp. 21-28; no 149, 31 de marzo de 1894, pp. 42-45. 
"la ley ineludible de la humanidad", 34 y con ello plantea una analogía entre la francmasonería y el budismo, al que considera con simpatía (en notorio contraste con la opinión citada antes de Gerardo Cabello), puesto que la consideraba como una religión que estimulaba la fraternidad, alentaba la eliminación de la jerarquía de castas y combatía el predominio de una casta sacerdotal (la teocracia). Lavergne sostenía que la moral predicada por Buda con su énfasis en la fraternidad era afín a la masonería:

"Neutralizar los impulsos de la pasión, llegar a la tranquila armonización de los intereses encontrados y encaminar las relaciones de los hombres por el sendero de la justicia, es la tarea en que la masonería se halla empeñada, como herencia de la misión iniciada por Budda con el movimiento social contra las desigualdades de que las castas eran triste presente; tarea que el espíritu de fraternidad, a medida de sus progresos, irá facilitando".35

Por tanto, se puede sostener que Lavergne se situaba claramente entre los masones que veían como indispensable la adhesión a una religión. Comentó aprobatoriamente las ideas vertidas por la conferencia, ya citada, del hermano Pedro M. Barrós que sostuvo que ningún ateo podía ser masón, ni la libertad afirmada por la masonería podía llevar a desconocer su carácter de institución "esencialmente religiosa" (véase pp. 7). Lavergne negaba también cualquier papel a la "escuela positivista" en la vida intelectual de las logias, y veía con desagrado que algunos Orientes europeos la hubiesen admitido. ${ }^{36}$

Sin embargo, hubo masones que no aceptaron la compatibilidad entre ciencia y religión que Lavergne propugnaba. Uno, bajo el alias de 'Redauvi', escribía que la ciencia era "la futura religión de la humanidad" pues permitía comprender "la ley del desarrollo progresivo de la naturaleza humana", y refutaba la "rutina Teogenética", paráfrasis con la que se refería a toda doctrina que postulara la creación del mundo por una divinidad, puesto que era una pretensión que estimaba ridícula por apelar a "causas extrañas e incomprensibles, a motores superiores, a potencias inútiles cuando menos". ${ }^{37}$ Por ello aseguraba que no bastaba

34 Eduardo Lavergne, "Estudios históricos sobre la masonería. III. Budda": RMP, no 152-153, junio y julio de 1894, pp. 81-89 (cita en p. 81).

35 Ibid., p. 89.

36 "Crónica": RM, no 10, 1 de setiembre de 1882, pp. 19-20.

37 Redauvi, "La ciencia. La instrucción superior en el Perú”: RM, no 13, 1 de diciembre de 1882, pp. 83-86. 
la ampliación de la instrucción primaria para formar buenos obreros y artesanos, sino que era necesario impulsar la instrucción superior con énfasis en la ciencia. ${ }^{38}$ Es una visión que prescinde de la divinidad, y que provocó la respuesta del deísmo masónico representado por el hermano Romería, quien para refutar esta "doctrina neo-panteísta" señala que existe una voluntad soberana, a la que concibe como mente divina no sujeta a ley, y a la que llama "Dios". 39

La publicación masónica no negó sus páginas a los que asumían una visión del universo puramente científica. Así se fue publicando por entregas el trabajo 'Primitivos seres humanos', de Antonio María Flores, que ya había aparecido en Los Debates de Sevilla (España), donde se presentaban argumentos contra la idea de creación ex nihilo, y se concluía que la divinidad era la misma naturaleza. ${ }^{40}$ En esa misma línea, se publicó 'Unidad de la materia', tesis que Margarita Práxedes Guerrero presentó para graduarse de Bachiller en la universidad de San Marcos. La autora, siguiendo las ideas del biólogo alemán Ernst Haeckel (18341919), desarrollaba una visión materialista y aseveraba que tanto la vida orgánica como la inorgánica tenían un solo origen (es decir, se adhería a la llamada teoría monista de la materia). ${ }^{41}$ Se publicaron asimismo artículos que presentaban el difícil camino que la ciencia

\footnotetext{
38 Ibid., p. 85.

39 Romería, "El desarrollo en el tiempo es la ley de la libertad y del progreso": RM, no 13, 11 de diciembre de 1882, pp. 89-94 (citas en pp. 89 y 90).

40 "Primitivos seres humanos": RMP, no 99, 31 de enero de 1890, p. 21.

41 "Unidad de la materia”: RMP, no 111, 31 de enero de 1891, pp. 7-10. Este trabajo fue publicado también en 1895 en El Pensamiento, revista científica que publicara la escritora argentina Carlota Garrido de la Peña en Santa Fé, Argentina. Allí llegó Práxedes Muñoz, procedente de Chile (Sosa de Newton, s.f.). Haeckel fue autor de Die Welträtsel (traducido como Los enigmas del universo), definido como vademecum popular de fines de siglo XIX en que se habían resuelto seis de los siete enigmas del universo. Del libre albedrío - enigma no resuelto- Haeckel decía que era "un simple dogma, basado en una ilusión, sin existencia real", Arthur Koestler, Flecha en el azul, Buenos Aires: Emecé, 1953, p. 64. Sobre Guerrero y su trayectoria como una de las pocas mujeres en incursionar en el medio universitario a inicios del siglo XX, véase Fanny Muñoz Cabrejos, "Margarita Práxedes Muñoz. La primera bachiller en ciencias del Perú (1849-1909)”: En vidas desiguales. Mujeres, relaciones de género y educación en el Perú, Lima: Instituto de Estudios Peruanos, 2018, pp. 59-87.
} 
había recorrido para hacerse valer frente a las imposiciones de la religión. 42

Para los masones la creencia en un ser superior no era obstáculo a su decidido anticlericalismo, más bien era un acicate para distanciarse de la Iglesia, a la cual veían como vetusto organismo que negaba los auténticos sentimientos religiosos mientras privilegiaba liturgias vacuas. Por ejemplo, M. C. Bonilla Castro declara en un poema: "No hay un altar que ofrezca incienso,/ ni una iglesia que cuente mi presencia,/ ni una secta que me halle entre su censo./ Mas creo en Diós!..".43 En síntesis, la masonería peruana si bien no admitió el ateísmo como tal, procuró legitimar una visión racionalista religiosa. Sin embargo, los pasos que dieron para definir una identidad del varón ni cristiano ni católico, es decir, del deísta en suma, fueron muy cautos y hasta inciertos. Veamos lo que dice Remigio B. Silva (n. Trujillo 1876-?) ${ }^{44}$ en una semblanza del poeta chalaco Jesús Benavides y Valdivia, a raíz de la publicación de su poema 'Vigil' en las páginas de la Revista Masónica. Silva inicialmente afirma:

"Sus creencias religiosas son por lo demás francas y libres: no es hijo de la Iglesia, ni piensa en guarecerse bajo los pliegues desgarrados de su manto.../ Se adapta

\footnotetext{
42 Como ejemplos podemos citar Andrew Dickinson White (1832-1918), "Las luchas de la astronomía": RMP, no 140, 30 de junio de 1893, pp. 114-120; Juan Guillermo Draper (1811-1882), "Historia de los conflictos entre la religión y la ciencia": RMP, no 141, 30 de julio de 1893, pp. 187-188. Fue Draper un metodista angloestadounidense, su obra fue traducida en Madrid en 1876 y 1886, por el científico español Augusto Arcimís Wehrle (1844-1910), en línea: http://www.filosofia.org/ave/001/a029.htm [07.11.20] y https://cultura cientifica.com/2016/07/29/augusto-arcimis-ampliando-horizontes/ [07-112020]. También se publicó a Alfred Russel Wallace (1823-1913), "El progreso humano, su pasado, su provenir": RMP, no 160, 2 de febrero de 1895, pp. 36-40 y no 161, 31 de marzo de 1895, pp. 49-54. Wallace fue un naturalista británico que planteó una teoría de la evolución, en línea: https://www.biografiasyvidas. com/biografia/w/wallace. htm [07-11-2020].

43 M. C. Bonilla Castro, "Profesión de fe (Callao, 1893)”: RMP, no 136, 28 de febrero de 1893, p. 32.

44 Esteban M. Cáceres, España en el Perú, en línea: http://www.cervantesvirtual.com/obra-visor/espana-en-el-peru--0/html/ ff49c66c-82b1-11df-acc7-002185 ce6064_4.html [14-11-2020].
} 
a la moderna escuela, que quiere luz a todo trance y se adelanta y divisa los grandes horizontes del futuro". 45

Sin embargo, no da una definición clara de la religión de Benavides:

"Su religión está exenta de personificar a un dios, de ceñirse a los estrechos límites del dogma.../ Tiene la consistencia de un anhelo; eterno y fugaz al mismo tiempo, es el ideal del progreso. La propaganda del bien, la religión del porvenir: la fe en el adelanto". 46

Después de mencionar las ideas religiosas de distintos escritores, Silva concluye que Benavides

"tal vez no piense cual ninguno de ellos y, haciendo una síntesis de lo que estos grandes hombres creían y estudiaban, tomando por punto de partida, la naturaleza, se forje allá, en lo íntimo de su conciencia, bajo el fulgor plácido de su pensamiento, una religión especial, informe, múltiple, en sus relaciones con la Humanidad, saludable, en fin, bajo todo punto de vista a las arduas lucubraciones de su espíritu." 47

Silva no emplea términos como deísmo, ateísmo, agnosticismo, quizá para evitar una aproximación directa a la cuestión, pero la afirmación de fondo es que lo íntimo de la conciencia de la persona es el reducto o ámbito donde se forman las convicciones religiosas, y que los encuadramientos externos son prescindibles.

Es probable que los incrédulos y agnósticos mantuvieran dentro de la masonería un perfil discreto, a la vez que impulsaban la divulgación de temas científicos para exponer una concepción del mundo ajena a lo divino. Así se explicaría que no se produjera una ruptura entre creyentes y no creyentes en un debate ideológico abierto. Antes bien fue una cuestión de ritual masónico lo que produjo un cisma en el seno de la GLP fundada en 1882. El principal protagonista fue Christian Dam (1852-1920), elegido Gran Maestre en junio de 1896. De origen inmigrante, Dam había llegado al Perú en 1869 desde Cuba para practicar su profesión de dentista y es probable que ya entonces contara

\footnotetext{
45 Remigio B. Silva, “'Vigil' por Jesús Benavides y Valdivia”: RMP, no 166, 31 de agosto de 1895, pp. 125-132, esp. pp. 125-126.

46 Ibid., p. 127.

47 Ibid., pp. 127-128. El estudio de Silva concluye en RMP, no 167-168, 10 de setiembre de 1895, pp. 145-150 (palabras en cursiva por mí). Puede tener interés también para la historia de la crítica literaria peruana del siglo XIX.
} 
con vinculaciones masónicas. ${ }^{48}$ Dam parece haber conocido de manera profunda la historia, la normativa y la organización masónica, lo cual era de vital interés en el país que, a raíz de la guerra, había quedado muy empobrecido y cuyas vinculaciones culturales e intelectuales habían quedado interrumpidas o debilitadas. En especial, los hermanos de la entonces joven GLP requerían esta orientación porque los miembros de los cuerpos masónicos más antiguos muchas veces aprovechaban el desconocimiento que la mayoría de los masones tenía de su propia tradición. Por ejemplo el Supremo Concejo 33, que se regía por el rito escocés, pretendió socavar a la recién fundada GLP con la especie de que no podrían practicar dicho rito por haberse adherido sus logias al de York. ${ }^{49}$ Así que la Revista Masónica sirvió para publicar textos fundamentales de esa tradición con el fin de ilustrar y mejorar el desempeño de los propios masones en su vida logial.

Dam, fue elegido Venerable en 1897, dictó un decreto el 13 de junio de 1897 que eliminaba la Biblia del altar masónico, fundándose en el lindero $21^{\circ}$ que estatuía que el juramento masónico se efectuara sobre "un libro de la ley", sin especificar cuál fuera este. ${ }^{50}$ De ahí en adelante el ceremonial debía realizarse colocando un ejemplar de las constituciones masónicas y otro de la constitución del Perú, tal como sucedía en varios orientes (Francia, Suiza, Italia, Portugal, e incluso en el Supremo Consejo grado 33을 del Perú). ${ }^{51}$ Esto fue celebrado por los masones de Trujillo quienes señalaron que la Biblia era un

"libro ridículo, inmoral y que constituye el Credo y el fundamento de una secta, con la cual los masones, que solo exijimos la creencia en Dios y en la inmortalidad del alma, nada tenemos que ver",

48 Se pueden hallar datos biográficos de C. Dam en Manuel Zanutelli Rosas, Periodistas peruanos del siglo XIX. Itinerario biográfico, Lima: Universidad de San Martín de Porres, 2005, pp. 95-96.

${ }^{49}$ Editorial, RM, no 8, 15 de mayo de 1882, p. 45. También J. A. Ego-Aguirre, alias Ricaurte, escribió un artículo titulado "Ritos": RM, nำ 5, 15 de abril de 1882, pp. 30-31.

50 Memoria del Gran Maestre Dr. Christian Dam presentada a la M.R. Gran Logia del

Perú en la sesión anual de 1897, Lima: Impr. La Industria, 1897, p. 37.

51 “Gran Logia del Perú": ELP, no 70, 2 de octubre de 1897, pp. 276-277. 
e incluso llegaron a plantear que se realizara un congreso de librepensadores en la capital. ${ }^{52}$ La logia limeña Honor y Progreso № 5 también acató la medida, pues su Venerable, Miguel Denegri, declaró en su memoria del año 1897 que se había quitado la Biblia de su altar para colocar las Constituciones de la Gran Logia del Perú. ${ }^{53}$ Las logias Luz del Guayas № 10, Constancia y Concordia № 11 (Tacna), Perseverancia № 12 (Callao), Cosmopolita № 13 (Trujillo), Fraternidad Universal № 20 (Arica), Porvenir de Huacho № 23, Luz de Pichincha № 31, Unión y Esperanza № 32 (Tocopilla) aceptaron excluir la Biblia de sus altares, pero en Lima solo las logias Orden y Libertad № 2 y Honor y Progreso № 5 aceptaron la medida con entusiasmo. Ya en octubre de 1897, en $E l$ Libre Pensamiento (ELP) se informa de un "motín de las logias" encabezado por la logia Kosmos № 7, la cual tenía la particularidad de ser integrada exclusivamente por ingleses y norteamericanos, situación que llevó a Dam a presentar su renuncia irrevocable. 54

\section{El librepensamiento y el derecho a no creer}

Existía pues una tensión íntima en la propia masonería que buscaba ser ese espacio de debate racional que escapara de la asfixiante tutela del clero y sus partidarios, donde se pudiera forjar proyectos de convivencia y entendimiento que sirvieran de puntos de apoyo para su actuación en la sociedad. Pero a la vez aquellos que seguían hasta sus últimas consecuencias el derrotero de la libertad de conciencia podían encontrarse en disputa con muchos de sus hermanos masones inclinados, fuera por ortodoxia masónica y/o por temperamento, al

52 “La Gran Logia del Perú (La Razón de Trujillo no 546)”: ELP, no 66, 4 de setiembre de 1897, p. 262.

53 “Sección masónica. Resp.• Log. • Honor y Progreso Núm. 5”: ELP, no 90, 19 de febrero de 1898, pp. 258-259.

54 "Sesión trimestral ordinaria": ELP, no 71, 9 de octubre de 1897; "Renuncia del M.• R. Gran Maestre": ELP, no 72, 16 de octubre de 1897. Unos cuantos masones firmaron en apoyo de Dam, entre estos destacan Lanfranco y Miguel Denegri. También la logia Regeneración Fraternal № 9 aprobó una moción a favor de C. Dam, "El h. . Dam y la Masonería": ELP, no 77, 20 de noviembre de 1897, p. 306. El Gran Oriente de Lima inscribió su nombre en el Gran Libro de Oro por su lucha por la idea liberal (Ibid.). 
deísmo tal como estaba formulado no solo en los "linderos", sino también en la constitución masónica. ${ }^{55}$

Durante su mandato Dam también promovió el librepensamiento sustituyendo la Revista Masónica, con El Libre Pensamiento como órgano de la GLP, el cual comenzó a publicarse dos veces por semana a partir del 27 de junio de 1896. Asimismo, Dam buscó incluir en la masonería personas de tendencia radical. Entre estos puede señalarse a Glicerio Tássara, iniciado en la logia Virtud y Unión № 3, quien ulteriormente editaría La Idea Libre y después adoptaría la ideología anarquista. En la misma logia se inició el geólogo Carlos I. Lisson (18681947); 56 el tipógrafo Nicanor Heraud, que dirigía el semanario El Obrero, se inició en la logia Orden y Libertad № 2.57

55 Este principio es el siguiente: “La Gran Logia de los Antiguos, Libres y Aceptados Masones de la República del Perú, reconoce y proclama la existencia de Dios y la inmortalidad del alma", enunciado en el título preliminar de la constitución de la Gran Logia, RM, no 4, 1 de abril de 1882, p. 21. Por otra parte los llamados linderos o landmarks no 19 y 20 de la ley masónica insistían en que creer en Dios como Gran Arquitecto del Universo era fundamental, por tanto la incredulidad en este era impedimento para adherirse a la masonería, y aseguraban que no había ningún precedente que mostrara que un ateo hubiera sido hecho masón; la creencia en la resurrección a una vida futura también era una consecuencia de la anterior, pero se reconocía que no estaba tan remarcada como el anterior principio, pero se consideraba que recorría todo el simbolismo de la Orden masónica, "Los fundamentos de la ley masónica": RM, no 815 de mayo de 1882, p. 46.

56 “Resp. . Logia Virtud y Unión, no 3”: ELP, no 66, 4 de setiembre de 1897, p. 258. Datos biográficos en Alberto Tauro del Pino, Enciclopedia ilustrada del Perú. Síntesis del conocimiento integral del Perú, desde sus orígenes hasta la actualidad, Lima: Peisa, 1987, vol. III, p. 1175.

57 "Sección oficial": ELP, no 66, 4 de setiembre de 1897, p. 258. El semanario El Obrero se publicó desde marzo de 1875 a diciembre de 1877 y tuvo la protección del Partido Civil. En su equipo editor, en que figuraban integrantes de la Sociedad Tipográfica de Auxilios Mutuos, estaba Manuel N. Heraud, tipógrafo. La inicial N. probablemente corresponda al nombre Nicanor. El semanario tuvo una postura liberal con tintes anticlericales, y acogió al menos un artículo crítico con la Iglesia en que se sugería que esta había distorsionado el cristianismo, Ulrich Mücke, Política y burguesía en el Perú. El Partido Civil antes de la guerra con Chile, Lima: Instituto Francés de Estudios Andinos / Instituto de Estudios Peruanos, 2010 pp. 246, 250-251. Un análisis pormenorizado de El Obrero y otros periódicos de artesanos de la época se encuentra en Íñigo García-Bryce Weinstein, República con ciudadanos. Los artesanos en Lima. 1821-1879, Lima: Instituto de Estudios Peruanos, 2009, pp. 221-249. 
Durante el lapso en que sirvió de órgano de la GLP, se apreció en $E l$ Libre Pensamiento una renovada energía en defender la separación entre Iglesia y Estado, y en intervenir de manera activa en la cosa pública, por ejemplo, en las elecciones municipales de 1897 promoviendo a los candidatos liberales. ${ }^{58}$ En su primer número planteó que abriría sus páginas a todo tipo de liberales: "doctrinarios, radicales y conservadores".59 Pensaban que así contribuían a un mejor entendimiento en la sociedad, y al cambio creando un espacio de intercambio de ideas. En su editorial enfatizaban que la masonería combatía la ignorancia causada por el fanatismo y buscaba hacer efectiva la tolerancia en el país, 60 aunque pronto sufrieron un desengaño, y abandonaron esta política de puertas abiertas. ${ }^{61}$ Tampoco fue alentadora la reacción de la prensa católica, cuyos portavoces conminaron a los lectores de El Comercio a no adquirir este diario mientras este diera noticias de la aparición de El Libre Pensamiento; para decepción de sus redactores, El Comercio se plegó a la presión católica. ${ }^{62}$ Se publicaron artículos críticos sobre temas relativos a la sociabilidad familiar y el sistema de relaciones entre los sexos. ${ }^{63}$ Retrospectivamente se puede apreciar que el período que vivió la GLP bajo la dirección de Dam fue un momento de apertura de la masonería. El Libre Pensamiento, como órgano todavía de la GLP, se esforzaron por divulgar nuevas opciones espirituales publicaron artículos con contenidos alternativos (por así llamarlos), como ‘El diablo' del Fabián Palasí Martín (Aragón 1848-1927), pedagogo masón y espiritista que se

58 En este tema se destacó la pluma de "Rosbar", alias masónico de Pedro E. Barrós, alentando la idea de una confluencia de "la Unión Cívica, el Club Universitario, la Unión Nacional, las Sociedades Unidas, la masonería y los círculos independientes" tras las consignas liberales, "Nuevas Elecciones": ELP, no 46, 17 de abril de 1897, p. 181.

59 "Aviso editorial": ELP, no 1, 27 de junio de 1896, p. 1. Al parecer, Eduardo Lavergne suspendió la edición de la Revista Masónica del Perú, y se retiró "a los balnearios", ELP, n- 2, 1 de julio de 1896, p. 6.

60 "Al comenzar": ELP, no 1, 27 de junio de 1896, p. 1.

61 "Aviso editorial": ELP, no 9, 1 de agosto de 1896, p. 1, donde anuncian que solo publicarán artículos afines al librepensamiento.

62 “Crónica": ELP, n 52, 29 de mayo de 1897, p. 203.

63 Así, "Corrupción social”: ELP, no 55, 19 de agosto de 1897, p. 258, en que se afirmaba que el descontrol de la natalidad llevaba al abandono de niños. 
fue publicando por entregas tipo folletín. ${ }^{64}$ Enrique López Albújar (Chiclayo 1872-1966), escritor y militante liberal, dio una conferencia en que planteó la incompatibilidad entre Jehová y Cristo, y denunció al "buitre carnicero de la teocracia", es decir, a la institución sacerdotal.65

Sin embargo, el cisma institucional en la propia Gran Logia del Perú, a la que Dam se vio obligado a renunciar, hizo que los partidarios del librepensamiento reevaluaran el papel de la masonería, y concluyeron que estaba condicionada por un "estado social de pusalinimidad e ignorancia" 66 como el peruano, por lo que solo podía tener una evolución lenta y tropezar continuamente con la incomprensión de incluso los propios liberales. De modo que vieron necesario independizarse por medio de una prensa autónoma que abiertamente luchara por los valores de la justicia y la fraternidad atendiendo a una "exigencia social". 67

Dam negoció para hacerse con el control de El Libre Pensamiento, el cual desde el 6 de noviembre de 1897 pasó a ser un "Semanario consagrado a la defensa y propaganda de las doctrinas liberales", 68 y desde el número 115 publicado el 13 de agosto de 1898, fue designado además como órgano de la Liga de Librepensadores del Perú, institución fundada por Dam. En esta nueva etapa del ELP se siguió dando espacio a noticias de la masonería en la "Sección masónica", y Dam siguió contando con la adhesión de varios masones inclinados al librepensamiento, a la vez que se fue haciendo más pronunciada la distancia con los que llamó "masones bíblicos". La Liga del Libre Pensamiento del Perú era una organización distinta a la masónica, no tenía rituales ni secretos, y apostaba decididamente por la laicalización de la vida social peruana y la "libre investigación de la verdad", sin poner cortapisas al cuestionamiento de los dogmas religiosos. Se fundó en la casa del propio Christian Dam el sábado 30 de octubre de 1897. Dam fue electo director, Glicerio Tássara, tesorero, y Gustavo Guerrero Luna, administrador. ${ }^{69}$ Los temas religiosos fueron abordados con más

64 La serie se inicia en ELP, no 29, 19 de diciembre de 1896, pp. 118-119.

65 "Los dioses bíblicos": ELP, no 61, 31 de julio de 1897, pp. 239-240.

66 "Al continuar": ELP, nํ 75, 6 de noviembre de 1897, p. 298.

67 Ibid.

${ }^{68}$ Sobre la actividad de la liga y su organización, véase Valdivia, El liberalismo social en el Perú, pp. 149-191.

69 “Crónica": ELP, no 75, 6 de noviembre de 1897, p. 300. 
claridad y decisión sin ahorrar críticas a los masones que se mostraran tibios en la defensa del laicismo. ${ }^{70}$

$\mathrm{Al}$ independizarse de la masonería, Dam comenzó a publicar en $E l$ Libre Pensamiento diversos textos que cuestionaban frontalmente la religión revelada, y el periódico se constituyó en un foro para la divulgación de una gama de creencias religiosas más diversa que la aceptada por la ortodoxia estatal peruana. Se introdujeron temas de debate religioso y político: se abordó la cuestión del antisemitismo en Francia y se divulgaron apreciaciones sobre la cuestión judía. ${ }^{71}$ La línea de indagar en la historia de las religiones continuó con trabajos que buscaron definir las vinculaciones históricas y filosóficas del cristianismo con tradiciones orientales y asiáticas, etc. que propendían a convertir a Cristo en una figura profética más, insinuando incluso cierta relación con el socialismo. ${ }^{72}$ En esta línea se puede registrar la aparición en serie del drama histórico filosófico del político radical italiano Giovanni Bovio (1841-1903), ${ }^{73}$ 'Cristo en la fiesta de Purim', traducido por Glicerio Tássara. ${ }^{74}$ Se publicaron artículos en que se recorría la historia de la Iglesia con una mirada crítica, señalando los cismas, evaluando la mayor o menor racionalidad de sus dogmas, así por ejemplo encuentran meritorio que la Iglesia griega no reconozca la figura del Espíritu Santo, ni acepte la existencia del purgatorio y otros puntos. 75

En la línea de construir y propagar en el medio una tradición de librepensadores se publicaron biografías de pensadores cuestionadores y/o descreídos como el sacerdote socialista Felicité Robert de Lammenais (1782-1854), el escritor ruso León Tolstoi, o del librepensador gallego Ramón Verea (1833-1899), cuyos escritos y

70 Así lo demuestran artículos en apoyo de la derogación del artículo $4^{\text {o }}$ de la constitución en ELP, no 76, 13 de noviembre de 1897, p. 302.

71 "Ashaverus": ELP, no 90, 19 de febrero de 1898.

72 "Jesucristo Egipcio": ELP, no 245, 2 de febrero de 1900, p. 1; "Jesús mitológico": ELP, no 246, 9 de febrero de 1901; “Jesús y los antiguos evangelios”: ELP, no 247, 16 de febrero de 1901, p. 1; "Jesús socialista": ELP, nº 248, 23 de febrero de 1901, p. 1.

73 Sobre Bovio véase el Dizionario Biografico Treccani, en línea: https://www.treccani.it/enciclopedia/giovanni-bovio [07-11-2020].

74 Comienza a aparecer en ELP, no 254, 21 de abril de 1900, p. 4.

75 "La Iglesia griega": ELP, no 255, 21 de abril de 1900, p. 1. 
biografía aparecieron en diversos números. ${ }^{76}$ De manera que fueron entretejiendo una red cosmopolita de referencias para el librepensamiento local, que tuvo su correlato práctico en el esfuerzo por participar en el congreso de librepensadores que se iba a celebrar en Roma en 1904. Sin embargo, la Liga de Librepensadores no estuvo encargada directamente de formar la delegación peruana, sino Manuel González Prada que tenía una relación más laxa con la liga, y que al efecto formó un 'comité librepensador del Perú', directamente vinculado al Congreso Internacional de Libre Pensadores celebrado en Ginebra en $1902 .{ }^{77}$ Prada propuso a una serie de liberales y librepensadores para integrar el comité de Lima entre los que destacan Christian Dam, por supuesto, el político liberal Augusto Durand, Glicerio Tássara, Abelardo M. Gamarra ("el Tunante"). Una regla del comité era que la presidencia del mismo sería por turnos. ${ }^{78}$

En 1905 Dam publicó su folleto 'El dogma de la libertad de conciencia. Opúsculo radical' para distribuirlo gratuitamente. Allí se oponía a todas las religiones reveladas, y se proclamaba seguidor estricto del filósofo ilustrado Barón de Holbach (1723-1789), que entendía que toda la verdad se puede alcanzar a través del estudio de la naturaleza. El dogma de la libertad de conciencia prohíbe — según afirma- castigar a las personas por sus opiniones incluso si admiten las religiones reveladas, y más bien han sido los que se han adherido a estas religiones los que han procurado castigar y poner fuera de la ley a quien no lo hiciera. Seguidamente denuncia los sacramentos y entiende que una serie de

76 "Juan María Roberto de Lammenais. Clérigo librepensador francés, erudito filósofo y escritor radical”: ELP, no 345, 3 de enero de 1903, p. 1; “Conde Leon Tolstoy. Ilustre gran pensador ruso, novelista, radical y apóstol de la Idea y el pensamiento libre": ELP, no 352, 21 de febrero de 1903, pp. 1-2. De Verea publicaron "El cristianismo" y también su retrato, ELP, no 148, 1 de abril de 1899, p. 2. Sobre Verea, véase Enciclopedia universal ilustrada europeo-americana, Barcelona: Espasa-Calpe, s.f., vol. 67, p. 1477.

77 Manuel González Prada, “Congreso de Ginebra, I”: ELP, no 365, 23 de mayo de 1903, p. 1.

78 “Crónica. Delegación del Congreso librepensador de Ginebra” ELP, no 361, 25 de abril de 1903, p. 2. Hubo cierta difusión internacional de la constitución del comité librepensador en Lima, véase "Comité Librepensador del Perú": Las dominicales. Semanario Librepensador (Madrid), no 99, 16 de enero de 1903, p. 1 (incluye un retrato de C. Dam). Sobre la relación de González Prada con el librepensamiento, véase Valdivia, El liberalismo social en el Perú, pp. 182-191. 
afirmaciones sobre la naturaleza de Dios son simples sofismas (sigue a Ramón Verea); ve en la ceremonia de la misa una pantomima; contrasta el matrimonio religioso al que denuncia como objeto de escandalosos negociados, sometidos a sacramentos como la confesión, penitencia y comunión prácticas religiosas inmorales con el matrimonio civil en el que ve una fuente de armonía y un lazo moral auténtico. El matrimonio religioso con su indisolubilidad es "una tiranía insoportable". ${ }^{79}$ Postula que la educación asegurará a las mujeres liberarse de la "jaula religiosa ultramontana". 80 Finalmente augura que la libertad de conciencia, cimentada en la libre investigación de la verdad y la ciencia, destruirá todas las religiones reveladas, al exponer que son un tejido de mentiras e idolatrías. Aunque en ciertos pasajes parece Dam criticar solo la concepción de Dios de los católicos, sin aludir directamente la existencia de Dios, su adhesión a Holbach indica su adhesión al ateísmo materialista. ${ }^{81}$

${ }^{79}$ El dogma de la libertad de conciencia. Opúsculo radical, Lima: Imp. Liberal, 1905, p. 43.

80 Ibid., p. 45.

81 Sobre Paul-Henri Thiry, Baron de Holbach, véase The Encyclopedia of Philosophy, Nueva York / Londres: Macmillan Publishing Co. \& The Free Press, 1967, vol. 4, p.51. Resulta curioso que la única noticia previa que he hallado sobre la divulgación de De Holbach en el territorio peruano se remonte al siglo XVIII: en 1782 Santiago Ustariz, balanzario de la Casa de Moneda de Lima e hijo de Gaspar Urquizu Ibáñez, oidor de la audiencia de Lima, se autodenunció ante la Inquisición de la ciudad por haber leído 'Sistema de naturaleza' de dicho autor, el cual "le atrajo por la impugnación de la existencia de Dios y porque su autor atribuye "la maravilla que somos nosotros mismos y que nos rodea' a solo la acción y combinación de los cuerpos entre sí". Confesó haber compartido esa lectura con el dominico fray Mariano Arbites, y ambos llegaron a la conclusión de que la religión era una quimera, Pedro Guibovich Pérez, Lecturas prohibidas. La censura inquisitorial en el Perú tardío colonial, Lima: PUCP, 2013, pp. 108-112. Holbach publicó 'Systeme de la nature, ou des lois du monde physique et du monde morale' en 1770, bajo el seudónimo M. Mirabaud, dando como lugar de impresión Londres, aunque se imprimió en Amsterdam. Urquizu debe de haber leído la obra en francés, pues solo se tradujo al castellano en 1822, Lourdes Máiz Carro, “Barón d'Holbach. Sistema de la naturaleza. Edición preparada por José Manuel Bermudo. Editora Nacional, Madrid, 1982, 631 págs.": Anales del Seminario de Metafísica, 18 (1983), pp. 158-160. No sabemos en qué idioma leyó C. Dam las obras de Holbach. 


\section{Espiritismo, superchería y libertad: el librepensamiento contra el Dr. Sarak}

La crítica a la religión revelada se afianzaba asignando un papel preponderante a la ciencia para generar una concepción del mundo liberada de nociones providenciales. A la vez, la idea de que la ciencia pudiera fundamentar mejor la existencia de fenómenos espirituales era un campo que se abrió para los mismos científicos. Esta exploración no se veía en contraposición con una formación científica, ya que muchas veces sus cultores consideraban que la ciencia respaldaba sus convicciones e ideas sobre los espíritus, y algunos de sus exponentes eran personas de formación técnico-científica incuestionable. El químico inglés William Crookes (1832-1919), por ejemplo, consideró absolutamente creíble la manifestación de espíritus a través de médiums. ${ }^{82}$ En el Perú coincidentemente el campeón del espiritismo fue también un hombre de formación científica: Carlos Paz Soldán (Arequipa, 1844-Lima, 1926), promotor de la telegrafía y autor de una cartilla de telegrafía eléctrica, que alcanzó varias ediciones, además de textos sobre problemas nacionales. ${ }^{83}$

Sin embargo, la presencia del espiritismo en el Perú es más antigua, aunque poco conocida. Existió en Lima una 'Revista Espirita' publicada en 1864 por E. Prugue y C. Girardot, presumiblemente franceses, que tenían un almacén de útiles de escritorio en la ciudad. ${ }^{84}$ Su contenido

82 John Daintith (ed.), Biographical Encyclopedia of Scientists, Boca Raton: CRC Press, 2008 (3a edición), p. 160.

83 En una semblanza biográfica de Paz Soldán publicada por Evaristo San Cristóbal, "Los fundadores del Instituto Histórico del Perú. Semblanzas biográficas": Revista Histórica, 22 (1955-1956), p. 88, no se hace referencia a sus convicciones espiritistas.

84 El litógrafo Émile Prugue se registró en el consulado francés de Lima en 1852, Pascal Riviale, Una historia de la presencia francesa en el Perú del siglo de las Luces a los años locos, Lima: Instituto Francés de Estudios Andinos / Fondo Editorial del Congreso del Perú / Embajada de Francis en el Perú, 2008, p. 172, en línea: DOI: 10.4000/books.ifea.726 [07-11-2020]. En su establecimiento, situado en la calle Plateros de San Pedro, el pintor Francisco Laso (1823-1869) expuso sus lienzos 'La igualdad ante la ley' (llamado después 'Las tres razas') y ‘La lavandera' en 1859, Natalia Majluf, "Estudio introductorio”: Francisco Laso (ed.), Aguinaldo para las señoras del Perú y otros ensayos. 1854-1869, Lima: Instituto Francés de Estudios Andinos, 2003, p. 23, en línea: DOI: 10.4000/books.ifea.1162 [07-11- 
consistía casi exclusivamente en entregas de la traducción de 'El libro de los espíritus' de Alan Kardec, el fundador del espiritismo. Habían pensado publicarlo entero, pero consideraciones económicas hicieron que lo publicaran en partes semanalmente. También pretendían insertar noticias que confirmaran la doctrina espiritista. A partir del cuarto número comenzaron a publicar Imitación del Evangelio del mismo autor. Sin embargo, este esfuerzo tuvo corta duración si atendemos al hecho de que solo conservan siete números en la Biblioteca Nacional del Perú que van desde 17 de diciembre de 1864 a 28 de enero de $1865 .{ }^{85}$ En todo caso esta publicación indica que la obra de Kardec se conocía en Lima ya en la década de 1860.

Otros indicios de la divulgación de ideas y quizá prácticas espiritistas aparecen en Lima diez años después. El literato español Juan Martínez Villergas (1817-1894) que se estableció en el Perú entre 1876 y 1878, escribió desde Huacho a su colega Eduardo Bustillo (1836-1908) una carta cuyo contenido fue considerado espiritista en los medios afines a esa doctrina. ${ }^{86}$ Villergas mantuvo contacto con Ricardo Palma, y fue bien recibido por el círculo intelectual de Gorriti: una de sus integrantes, Manuela Villarán de Plasencia escribe el poema 'Al Sr. Don Juan M. Villergas' ${ }^{87}$ No es claro si este escritor contribuyó a fomentar el

2020]. También la asociación Prugue-Girardot funcionó como imprenta publicando algunos folletos a mediados del siglo XIX.

85 De la Revista Espirita se conservan siete números en la Biblioteca Nacional del Perú [BNP] que van desde 17 de diciembre de 1864 a 28 de enero de 1865.

86 "Crónica": Revista de Estudios Psicológicos, 4: 10 (1878), p. 120. "De la carta que nuestro compatriota el ilustre poeta D. Juan Martínez Villergas, escribe desde Huacho a su amigo Eduardo Bustillo en 26 de diciembre de 1877, extractamos el siguiente párrafo: 'Soy un alma que le ha dicho a su cuerpo: yo soy siempre virgen, yo soy siempre joven, voy a luchar en otra esfera, en otra vida; tú ya estás rendido, no me puedes ayudar; adiós anciano. Ése soy yo un hombre que se ha despedido de sí mismo.' Este es el lenguaje del Espiritismo".

87 El Recreo, no 20, 15 de noviembre de 1876, p. 201. El poema presenta a las escritoras de Lima y otras partes del Perú en la velada literaria celebrada en obsequio de Villergas en la casa de Juana Manuela Gorriti el 1 de noviembre de 1876, El Recreo, № 20, p. 204. Para referencias a la larga amistad entre Villergas y Palma, véase Osvaldo Holguín Callo, "Notas sobre la complicidad intelectual de Ricardo Palma y Juana Manuela Gorriti”: Aula Palma, 17 (2018), pp. 141-177. 
espiritismo en alguna medida en los medios intelectuales. ${ }^{88} \mathrm{El}$ ingeniero e inventor español Ricardo Caruana y Berard (Valencia 18??), activo espiritista que llegaría a ser secretario general del Centro Espiritista Español, residió en Lima hacia 1876. ${ }^{89}$ Son indicios de la propagación del espiritismo inicial a través de transeúntes extranjeros que visitan el país. Aunque se conoce poco de su arraigo antes de la guerra con Chile, se puede pensar que dio motivo de preocupación a los grupos de la elite cultural. Así tenemos que en El Recreo, revista publicada en el Cusco por la escritora Clorinda Matto de Turner, dio a conocer varios artículos del doctor Ricardo Villa, ${ }^{90}$ contrario al espiritismo, quien afirma haberse adherido inicialmente a esta doctrina en Lima, donde una mujer le prestó libros de Alan Kardec y además supo del caso de un joven que, alterado por la lectura de esos textos, quiso arrebatar la hostia consagrada al sacerdote oficiante por orden de un espíritu

88 Hacia 1878 se difundió el rumor en España de que Villergas había enloquecido en el Perú; el escritor aclaró que si bien no era el caso, sí se hallaba en una situación dificultosa económicamente. Con ayuda de sus colegas pudo volver a España en 1878, Salvador García Castañeda, "El satírico Villergas y sus andanzas hispanoamericanas”: Anuario de Letras. Lingüística y Filología, 8: 1 (2020), pp. 133-151.

89 Caruana escribe una carta en Lima, fechada en octubre de 1876 a su amigo el poeta chileno José Antonio Sóffia (1843-1886), adjuntado un poema sobre la forma de morir y la calidad moral del que muere, "Noticias": Revista de Estudios Psicológicos, 1: 10 (enero 1878), pp. 24-27. También véase "Noticias": El Criterio Espiritista, Órgano Oficial del Centro Espiritista Español, 7: 11 (1878), p. 140. Sobre la actividad de Caruana en Chile como ingeniero, véase Alberto Gurovich Weisman, "El proyecto como metáfora. La ética de la sustentabilidad en el discurso urbanístico de la experiencia chilena. 1835-1958": Cuaderno de Investigación Urbanística, 67 (2009), pp. 86-103.

90 Villa era muy probablemente de nacionalidad colombiana. Publicó "Conferencias sobre historia en la ciudad de Antioquia (Colombia)" en El Recreo desde el no 12 , 15 de julio de 1876 hasta el no 22,1 de diciembre de 1876. Allí expone una visión providencial de la historia, y básicamente relata la historia de la creación para refutar las ideas materialistas que niegan la existencia de Dios y su papel en la historia humana. Cesó de colaborar como director de la revista a fines de 1876, previamente. Probablemente se trató de Ricardo Villa, senador por el Estado de Antioquia, que aparece firmando la constitución política de la Confederación Granadina de 1858, Actos lejislativos expedidos por el congreso nacional en 1858, Bogotá: Imprenta de la Nación, s.f., p. XVI. 
evidentemente maligno. ${ }^{91}$ Jerónimo Zavala, educador cuzqueño del que apenas se conoce, era un espiritista convencido e intentó polemizar con Villa. ${ }^{92}$ Solo logró publicar dos artículos en los que cuestionó las ideas católicas sobre el demonio y sobre todo la noción de penas eternas para las almas pecadoras, fundamentando sus ideas en los siguientes autores: Kardec, la autoridad nodal del espiritismo, Enrique Stecki, autor de 'El espiritismo en la biblia' (traducido en 1859), Eugène Nus, autor de 'Les grands mystères' (1866), y Jean Reynaud, que escribió 'Tierra y cielo' (1854). ${ }^{93}$ Villa, en cambio, quizá aprovechando su posición de director de la revista, publicó cinco artículos y concluyó que el espiritismo, al proponer que los espíritus desencarnados nos rodeaban de manera invisible, eliminaba el infierno, y por tanto destruía el freno moral que este significaba para los pecadores. Era por tanto una doctrina enemiga del catolicismo. 94

Tras la posguerra, como hemos mencionado, Carlos Paz Soldán tuvo un papel crucial en la divulgación del espiritismo. Su revista, El Sol, que se inició como bisemanario atento al acontecer político y económico de actualidad, comenzó a publicar en forma de folletín la novela 'Estudios espiritistas y vida de loco', basada en su estancia en el hospital de

91 Ricardo Villa, "La cuestión espiritista. Los demonios II": El Recreo, no 20, 15 de noviembre de 1876, p. 204. Por coincidencia el sacerdote oficiante era el franciscano Pedro Gual (1813-1890), ferviente detractor de los heterodoxos, Cristóbal Aljovín, "En defensa del papa y de la Iglesia. Los escritos del franciscano Pedro Gual. 1845-1890": Fabio Kolar / Ulrich Mücke (eds.), El pensamiento conservador y derechista en América Latina, España y Portugal. Siglos XIX y XX, Madrid: Iberoamericana / Vervuert, 2019, pp. 123-148.

92 Existe en la provincia cusqueña de Canchis, un colegio nacional que lleva el nombre de "Institución Educativa Jerónimo Zavala".

93 Jerónimo Zavala, "El espiritismo": El Recreo, no 19, 1 de noviembre de 1876, pp. 186-187, y no 20, 15 de noviembre de 1876, pp. 199-200. Al final de esta entrega del citado artículo se anunció la continuación, pero no se publicó.

94 Ricardo. Villa., "El espiritismo": El Recreo, no 16, 15 de setiembre de 1876, pp. 150-152. Aquí se menciona el desengaño con el espiritismo del intelectual colombiano Dr. Manuel María Madiedo (1815-1888). "El espiritismo": El Recreo, no 19, 1 de noviembre de 1876, pp. 184-185, 191-193; "Notas al artículo anterior": El Recreo, no 20, 15 de noviembre de 1876, pp. 200-201 (las notas se refieren al artículo de Zavala allí publicado); “La cuestión espiritista. Las reencarnaciones III": El Recreo, no 21, 1 de diciembre de 1876, pp. 209-211. También el artículo citado en la nota 70. Además, Villa publicó “Los librepensadores”: El Recreo, no 20, 15 de noviembre de 1876, pp. 204-206. 
insanos de San Andrés, donde fue internado pues se atribuyó sus actos violentos a la locura causada por sus prácticas espiritistas. ${ }^{95}$ En 1890, la revista se convirtió en El Sol, revista quincenal de Historia, Magnetismo, Estudios Psíquicos, con el fin de divulgar la doctrina espiritista dando a conocer textos traducidos del francés y el inglés, y aportes procedentes de países de lengua castellana. Tras ocho años de actividad, Paz Soldán anunció que debido a problemas económicos debía convertir su bisemanario en mensuario. ${ }^{96}$

Por su parte, los librepensadores consideraron su deber divulgar toda filosofía o sistema de creencias con el fin de poder hacer un examen crítico, para fundamentar su combate contra las 'supersticiones', y tratar de inducir al público a pensar en términos racionales y científicos. Por ejemplo, criticaron la credulidad de una serie de personas incluso ilustradas, y también denuncian la práctica de lanzar "funestas predicciones" con el fin de explotar la credulidad. ${ }^{97}$ La tarea de cuestionar estas ideas pasaba en parte por divulgarlas para poder hacer patente sus puntos débiles y reforzar el campo librepensador. Es así que dieron a conocer una comunicación de un llamado 'Supremo Consejo de Mahatmas del Tibet' junto con una breve noticia histórica referida a la propaganda religiosa indostánica. Identifican esta presunta religión con el budismo, al que consideran más racional que el cristianismo, aunque toda religión es por definición "superchería humana", sea la brahmánica, la budista, la espiritista, y ninguna tan dañina como la católica: el Papa romano es en su concepto una derivación espúrea del

\footnotetext{
95 La publicación se inició en El Sol, no 30, 15 de mayo de 1886, y concluyó en El Sol, no 67,5 de febrero de 1887. Después se publicaron textos sobre la novela, cartas y otros artículos sobre el espiritismo. Casi al mismo tiempo la novela se publicó como libro. Sobre los pormenores de su tratamiento psiquiátrico, véase Augusto Ruiz Zevallos, Psiquiatras y locos. Entre la modernización contra los Andes y el nuevo proyecto de modernidad. Perú. 1850-1930, Lima: Instituto Pasado \& Presente, 1994, pp. 51-71. Otra novela contemporánea de temática espiritista fue la publicada por el escritor colombiano radicado en Lima, Simón Martínez Izquierdo, Paseos por el orbe ideal. Diez y seis sesiones de espiritismo, Lima: Imp. Torres Aguirre, 1887. Martínez fue presidente de la Sociedad Colombiana de Beneficencia organizada en Lima, Almanaque del comercio de Lima, 2a parte, Lima: Imprenta del Estado, 1876, p. 238.

96 "Advertencia": El Sol, año 9, no 592, 1 de diciembre de 1894, p. 1.

97 "El fin del mundo": ELP, no 182, 18 de noviembre de 1899, p. 1.
} 
gran lama del Tibet.98 En consecuencia consideran inaceptables las doctrinas de dicho Supremo Consejo y de su delegado en Lima, el italiano Alberto Santini-Sgaluppi, llamado también Alberto Sarak, conde de Das, quien ejercía de médium espiritista a la vez que de enviado de los presuntos "mahatmas". 99

La irrupción de este espiritista en el medio limeño dio a los librepensadores una oportunidad de aparecer en la prensa convencional con un perfil polémico aún más destacado. Sarak había publicado sus trabajos en El Comercio de Lima, y había fundado un Centro Esotérico Porvenir del Perú en su domicilio el 26 de octubre de 1899, integrado por ocho varones. Eligieron como presidente a un miembro con las iniciales B. P. (Belisario Piedra?); vicepresidente a Carlos Paz Soldán; tesorero a H. B. Figari; secretario a H. J.; primer vocal a Amilcare Fasce; segundo vocal a E. Botteri; mientras que Federico Valle y C. Kroll figuraron solo como miembros activos. Poco después se produjeron algunas renuncias y asumió el cargo de presidente José Arturo Ego Aguirre, que en ese momento era también Gran Maestre de la Gran Logia del Perú; el sr. J. A. asumió la tesorería, y Sarak designó a H. B. Figari, delegado local del centro ante el Supremo Consejo del Tibet. Asimismo, Federico Valle ocupó el cargo de secretario, aunque pronto se ausentó y Sarak nombró como interino a F. C. Vila; C. Kroll fue nombrado primer vocal y como segundo quedó A. Fasce.100

En la sesión de 9 de noviembre de 1899 Sarak cayó en trance mediúmnico y un espíritu le ordenó buscar un lugar sin nubes para reunirse, entonces los del Centro realizaron una excursión a Chosica

98 "Los secticidas": ELP, no 191, 20 de enero de 1900, p. 1.

99 Sarak ejercía de médium y prestidigitador. Sus supercherías lo habían llevado a la cárcel en Italia, Bélgica, Francia y España. Fundó una serie de revistas de tipo esotérico: Philadelphia (Argentina), La Verdad (Valparaíso, Chile), El Loto (Lima). Muchas veces estas publicaciones no tuvieron continuidad debido a que Sarak dispuso de los fondos para su provecho personal. Sobre su papel paradójico como iniciador de la teosofía en Argentina, véase Soledad Quereilhac, La imaginación científica. Ciencias ocultas y literatura fantástica en el Buenos Aires de entresiglos (1875-1910), Buenos Aires: Instituto de Historia Argentina y Americana "Dr. Emilio Ravignani" (UBA / CONICET), 2010 (tesis doctoral), pp. 175-179.

100 Los nombres se toman de los firmantes de una carta de protesta por un artículo en El Tiempo que calificó de acto de prestidigitación una demostración del Dr. Sarak en el teatro del Callao, "Intereses generales": El Comercio [EC], 28 de octubre de 1899 (tarde), p. 4. 
financiada por sus miembros, y se fue perfilando la idea de establecer un local en Matucana. Otras actividades fueron la realización de experimentos fotográficos y la lectura de la obra La voz del silencio de Helena P. Blavatsky, la fundadora de la teosofía. ${ }^{101}$ Otra sesión, un domingo de febrero de 1900, contó con la presencia no solo de los miembros del Centro Esotérico sino con la de unos " 15 o 20 estudiantes de medicina" y el Dr. Sarak hizo una demostración de sus poderes psíquicos, que al parecer algunos encontraron creíbles.102 Una voz crítica lo acusó de ser un prestidigitador, pero no obtuvo más respuesta que el renovado apoyo a Sarak por parte de los miembros del Centro Esotérico Porvenir. 103

Aunque la Liga de Librepensadores solo admitía la racionalidad como medio para la libre investigación de la verdad, en una muestra de tolerancia, publicó un artículo de un colaborador de $E L P$, quien seguía las doctrinas de Sarak. El autor, del que se conoce solo el alias masónico, afirmaba que el ocultismo no se oponía a la ciencia, en apoyo de lo cual citaba a Raimundo Lulio, a Paracelso, a Nicolás Flanel, al conde de Cargliostro, a Swedenborg, etc., esto es, una serie de eruditos más ligados al ocultismo y a la alquimia que a la ciencia positiva. ${ }^{104}$ La línea editorial de ELP sostenía, antes bien, que la religión desaparecería a medida que se fuera imponiendo la ciencia: frente a la redención religiosa proclamaban que se operaría la redención científica. ${ }^{105}$ Fue Glicerio Tássara quien asumió la labor de esclarecimiento doctrinario por parte de la Liga: afirmó contra Sarak la identidad de la razón en todas partes del mundo, y subrayó que no era esta facultad lo que separaba la cultura hindú de la occidental, sino el concepto de la vida. También procuró refutar la noción de karma, o ley kármica, propugnada Sarak, y finalmente se esforzó por rebatir las doctrinas de la teosofía.

101 La difusión de la teosofía en los ámbitos de lengua castellana se inició en Barcelona en la década de 1890 con las traducciones del ingeniero Francisco Montoliu y Togoré. Véase María del Mar González de la Peña, "Francisco Montoliú y la Sociedad Teosófica Española”: Historia y vida, 332 (1995), pp. 72-75.

102 Veritas, “'El Libre Pensamiento' y el Dr. Sarak": EC, 6 de febrero de 1900 (tarde). 103 Carlos Fernández Pasalagua, "La psiquiatría del Dr. Sarak": EC, 11 de noviembre de 1899 (tarde), pp. 2-3; “Intereses generales. La psiquiatría del Dr. Sarak”: EC, 13 de noviembre de 1899 (tarde), p. 4.

104 Spero, "Ocultismo y teosofía”: ELP, no 193, 3 de febrero de 1900, p. 4. 105 “Doctrinarismo religioso": ELP, no 194, 10 de febrero de 1900, p. 1. 
Tássara también encontraba incoherente el propósito explícito de Sarak de estudiar la psicología moderna a la vez y pretender rescatar una antigua sabiduría atribuida a los "mahatmas", y atacaba también la noción de revelación utilizada por Sarak. ${ }^{106}$

Para rebatir a la Liga de Librepensadores Sarak publicó una serie de artículos en El Comercio a la cual calificó de secta.107 Tássara, el portavoz de la Liga, contratacó con referencias a la dudosa calidad moral de Sarak: veía oportunismo en el hecho de que diera conferencias en la Gran Logia del Perú, a la vez que planteaba una coincidencia de fondo con el catolicismo en algunos de sus escritos. ${ }^{108}$ Algunos partidarios de Sarak acudieron a su defensa y reprocharon a Tássara el haberlo tildado de embaucador y recalcaron la autenticidad de los poderes de Sarak; acusaron a la Liga de procurar eliminar el culto católico y de ejercer la intolerancia por insistir en que la revelación no se puede probar. ${ }^{109}$ Cuestiones más prosaicas dieron un giro a este debate. Pronto se supo que Sarak había intentado el 13 de marzo de 1900 aumentar la cuota de membresía del Centro y cobrar un elevado alquiler (30 soles) por el uso del local que, coincidentemente, era su propio domicilio, los miembros del Centro se resistieron a estas medidas, por lo que en represalia les quitó la carta constitutiva por la que habían pagado 100 soles. ${ }^{110}$ Sarak había desviado el dinero de las suscripciones cobradas en el Callao y las procedentes de diversos países para la proyectada revista 'El Loto' hacia su apartado postal. También se había apoderado de donaciones que tenían por objeto fundar una casa de salud en Matucana. Así comenzó a cundir la desconfianza y finalmente Sarak fue rechazado por sus

106 Glicerio Tássara, “Ocultismo y teosofía. Brahmanismo y Budhismo”: ELP, no 194, 10 de enero de 1900, pp. 1-2; “Ocultismo y teosofía. La religión del Dr. Sarak”: ELP, no 195, 17 de enero de 1900, pp. 1-2. "Ocultismo y teosofía. Algo sobre el método": ELP, no 192, 27 de enero de 1900, pp. 1-2.

107 Véase, por ejemplo "La luz en el sendero de la vida. Estudios filosóficos": EC, 23 de enero de 1899 (tarde), p. 3, y “Ocultismo y Telepatía”: EC, 23 de enero de 1899 (tarde), pp. 3-4. A esto Glicerio Tássara responde en "La teosofía del Dr. Sarak": EC, 29 de marzo de 1900 (tarde), p. 3.

108 “El Dr. Sarak y la 'Liga de Libre-pensadores'”: ELP, nº 193, 3 de febrero de 1900, p. 1.

109 Veritas, “'El Libre Pensamiento' y el Dr. Sarak” EC, 6 de febrero de 1900 (tarde), pp. 3-4.

110 "El Centro Esotérico 'Porvenir del Perú' y la gran farsa del Doctor Sarak Conde de Das": ELP, nº 202, 7 de abril de 1900, pp. 2-3. 
seguidores, razón por la que decidió abandonar el país. Un miembro del Centro intentó impedir su marcha para poder cobrarle deudas pendientes, pero no tuvo éxito. El pretendido conde partió de Lima el 31 de marzo de 1900, primero se dirigió a Salaverry, aunque su verdadero destino era Panamá, fuera del alcance de sus acreedores. Su principal valedor y colaborador en Lima el Dr. Carlos Paz Soldán pronto debió publicar una aclaración deslindando su responsabilidad económica con respecto a las deudas de Sarak. ${ }^{111}$ La Liga consideró que Paz Soldán había sido una víctima por su devoción al espiritismo,112 pero este, aunque decepcionado de Sarak, no perdió su fe en esa doctrina. Continuó publicando El Sol, y en sus páginas relató los fraudes del presunto doctor y conde para alertar al público interesado.113

\section{Disidencia religiosa en la provincia: el librepensador Ángel Chávez Patiño en el valle del Mantaro}

Es habitual referirse al episodio de los protestantes en Puno para indicar la reticencia y violencia con que se confrontaba cualquier búsqueda de caminos alternativos a la ortodoxia católica en el Perú del novecientos. ${ }^{114}$ Sin embargo, otros puntos del llamado interior del país se vieron agitados igualmente por nuevas ideas y por propuestas de una sociabilidad y religiosidad distintas. La Liga de Librepensadores obtenía una continua información sobre la situación religiosa de muchas localidades mediante corresponsales que denunciaban las procesiones

111 "A los espiritualistas de todas las creencias": El Sol. Revista de historia, magnetismo, estudios psíquicos, 3ํ período, 1 : 1 (1900), pp. 2-25. Sobre correrías de Sarak en Venezuela, "Sarak en Caracas": ELP, no 216, 14 de julio de 1900, p. 1.

112 "La despedida del Dr. A. de Sarak, conde de Das y el aviso del Dr. Paz Soldán": ELP, no 202, 7 de abril de 1900, pp. 1-2.

113 "A los espiritualistas de todas las creencias": El Sol, 3º período, 1: 1 (1900), pp. 225. Una posible secuela de este episodio es que a inicios de agosto de 1900, un Dr. Alfredo Brendt, que acababa de llegar "del sur", ofreció una conferencia en el local de la Verein Germania para explicar los fraudes espiritistas. Se notó la asistencia de muchas "señoras y señoritas". Brendt fue refutado por una persona con las iniciales C. A. V. que era favorable al espiritismo, "Sesión anti-esperitista”: EC, 5 de agosto de 1900, p. 2; "El titulado doctor Alfredo Brendt y sus prestidigitaciones": EC, 17 de agosto de 1900 (tarde), p. 3.

114 Sobre la prédica adventista y la reacción católica en Puno, véase Klaiber, La Iglesia, p. 140; Armas Asín, Liberales, protestantes y masones, pp. 190-197. 
y fiestas patronales como un mero escenario de superstición y permisividad para la embriaguez y una serie de costumbres desordenadas. La opinión de la Liga sobre la religiosidad existente era drásticamente negativa y consideraba que debía ser totalmente eliminada:

"Los pueblos religiosos son pueblos enfermos, pueblos podridos, incapaces de conseguir por sí propios un puesto digno en el concierto del mundo; y el Perú no debe consentir jamás ser envuelto en este oleage de fango que se llama la Religión de Cristo y de León XIII".115

Por tanto, la Liga de Librepensadores del Perú y sus delegaciones alentaban una visión laica y una religiosidad despojada de este tipo de manifestaciones (las fiestas de cargos, procesiones, novenas, etc., la acción de cofradías, etc.). Su órgano de prensa propalaba noticias de la lucha por el laicismo y la libertad de conciencia en distintos puntos de la república y hasta del mundo. En suma, adoptaron una actitud crítica y distante frente al complejo de prácticas que a la larga se ha convenido en llamar 'cultura popular', algunos de cuyos usos y costumbres actualmente se busca preservar incluso bajo el marbete de 'patrimonio inmaterial'.

Desde este punto de vista, la causa que comprometió a los librepensadores de la zona del valle del Mantaro resulta significativa. $Y$ parece haber dejado cierta huella en la conciencia conservadora, pues José de la Riva Agüero ya en 1912 justamente al visitar el convento de Ocopa atribuyó las deficiencias arquitectónicas de su templo a los incendios que había sufrido y que fueron probablemente motivados por "el estúpido y grotesco anticlericalismo serrano".116 Se refiere así a los sucesivos incendios ocurridos en Ocopa en junio de 1899 y que fueron atribuidos a los librepensadores del lugar.

Efectivamente, la Liga de Librepensadores del Perú contaba con una serie de delegaciones en las principales ciudades del valle del Mantaro: en Concepción se había fundado una el 13 de enero de 1898, otra en Huancayo el 30 de marzo de 1898 y finalmente otra en Jauja el 9 de octubre de 1898.117 La más activa parece haber sido la de Huancayo,

115 "Clericalismo": ELP, no 140, 4 de febrero de 1899, p. 1.

116 José de la Riva Agüero, Paisajes peruanos, obras completas, Lima: Pontificia Universidad Católica del Perú, 1960, vol. 9, p. 221.

117 Abel J. Vega, “Huancayo”: ELP, no 232, 3 de noviembre de 1898, p. 3. 
presidida por Ángel Chávez Patiño (Concepción, 1863-?). Se conoce algo de su persona a través de una semblanza negativa publicada por sus detractores: se educó en el colegio Santa Isabel de Huancayo hasta primero de secundaria, pronto se vio abrumado por una serie de penalidades producto de una violencia aguda que se presenta como una suerte fatal e individual: su padre, natural de Tarapacá, fue asesinado en su presencia; también su cuñado fue víctima mortal de unos ladrones; finalmente, sufrió graves quemaduras en una hacienda de Tayacaja donde trabajaba. Para sostenerse comenzó a trabajar en un taller de carpintería, pero por razones de salud se hizo vendedor de libros de primaria. En 1896 llegó a Huancayo el Dr. Wood, predicador protestante, y Chávez se convirtió al protestantismo y se hizo vendedor de biblias. ${ }^{118}$ Esta conversión fue acompañada de un gran activismo social, pues estableció una sociedad de artesanos, integrada por los que prestaban oídos a su prédica religiosa, y también imprimió todos los decretos que declaraban que la primicia que se pagaba a los curas no era obligatoria e instruyó con estas novedades a los indios que iban a su tienda. Los autores del artículo consideran que Chávez se asoció a la Liga de Librepensadores, juzgando equivocadamente que con ello ayudaba a propagar el protestantismo, por ello se formó contra él un frente de enemigos: los padres misioneros, los curas de los pueblos y las señoras de Huancayo, Concepción y Ocopa, todos los cuales exigían que Chávez fuera excomulgado, mientras que 'los hombres sensatos' de la localidad vieron esta pugna con indiferencia. En 1898 un cura desafió a Chávez a debatir en una conferencia pública, tras la cual cada uno de los ponentes se proclamó vencedor. Los articulistas dicen que después la actividad de los librepensadores se fue extinguiendo por falta de recursos, y que Chávez se retiró de la escena pública, sin embargo, su acción tuvo el efecto de que los huancaínos en general fueran etiquetados de herejes, masones o diablos por sus vecinos. Afirman que, aunque las reuniones de librepensadores de Huancayo estaban en receso, cuando ocurrió el primer incendio del templo de Ocopa se les mencionó. ${ }^{119}$

Las primeras noticias del incendio del templo de Ocopa provienen de comunicaciones oficiales y cables de telégrafos del Estado. Ocurrió en la

\footnotetext{
118 Una nota en un diario neoyorkino reportando el incendio describía a Chávez como discípulo del Dr. Wood, "Peruvian Convent Burned. The Natives Attribute the Loss to American Missionaries": New York Times, 25 de junio de 1900. 119 Huancaínos, “Los incendios de Ocopa”: EC, 1 de agosto de 1900, p. 3.
} 
madrugada del sábado 16 de junio de 1900. Quedó el coro consumido, y el resto averiado (altar mayor, cruceros, media naranja). Se informa de que puede ser obra de una "mano incendiaria y malévola".120 Un segundo incendio se produce el 22, casi a las 6 am. Entonces entra en escena una multitud (la "indiada") acusando al huancaíno Francisco Zevallos de esta acción. ${ }^{121}$ También se cree sospechoso a un lego del convento. ${ }^{122}$ Días después, la versión enviada por el prefecto de Junín, Elías, asegura que estaban complicados en el hecho específicamente a Ángel Chávez Patiño y a Gerardo Bian, ambos de Huancayo. También capturan a un "chunchito" considerado "instrumento" de un hombre llamado Luis Urrutia y Pineda de Quichuya. ${ }^{123}$ Luego esta versión se desmiente. Entra en acción el juez de 1a instancia de Jauja, Lizardo Velazco, quien según una información llegada de Huancayo habría dicho: "Huancayo pide que no se traslade a Chávez, pero como católico, sea o no culpable, me las habré con él y haré escarmiento en los huancaínos". ${ }^{24}$ Se menciona que una multitud (llamada "el populacho" por el redactor) reunida en Santa Rosa de Ocopa gritaba: "Mueran los huancaynos herejes". ${ }^{125} \mathrm{El}$ incendio es un detonante de la rivalidad entre Huancayo y Jauja, en que la primera como ciudad de modernidad emergente en la sierra central aparece como generadora de males y disturbios, mientras que la segunda, a la defensiva en su tradicionalismo y respetabilidad, encuentra en la religión una causa aparentemente inatacable y un medio de afirmar un predominio regional en cuestión.

Un grupo que firma como Huancaínos publicó una carta abierta para relativizar las dimensiones del episodio. D que en el primer incendio se quemó apenas un órgano, y en el segundo solo el altar de San Vidal. Señalaron que los telegramas habían exagerado los daños, y que, al ocurrir el segundo incendio, un presunto testigo acusó a Chávez.

120 “Crónica”: EC, 16 de junio de 1900 (tarde), p. 1; “El Día. Incendio del convento de Ocopa”: EC, 17 de junio de 1900, p. 1; "El incendio de Ocopa (por los telégrafos del Estado)": EC, 20 de junio de 1900 (tarde), p. 1.

121 Se dice después que Zevallos era un joven minero que había ido a buscar barreteros para su mina y se encontró envuelto en la asonada, y fue defendido de la "horda de indios armados" azuzada por beatas, por sus parientas y unas colegialas, Huancaínos, "Los incendios de Ocopa": EC, 1 de agosto de 1900, p. 3. 122 “El Día. Nuevo incendio de Ocopa”: EC, 22 de junio de 1900 (tarde), p. 1.

123 "El incendio de Ocopa. Versión oficial y telegramas", EC, 24 de junio de 1900, p. 3. 124 "Interior. El incendio de Ocopa": EC, 26 de junio de 1900 (tarde), p. 1.

125 Ibid. 
Consideraban que el juez Velazco era un fanático religioso y su único propósito era escarmentar a Chávez, y no esclarecer la verdad. Los huancaínos se mostraron desdeñosos de la capacidad intelectual de Chávez y de sus seguidores artesanos, pero se aunaban al "vecindario sensato de Jauja y Huancayo" en considerarlo inocente: "este pobre hombre es otro Dreyfus del siglo XIX".126 Es posible que los huancaínos que suscriben esta carta fueran liberales de elite que prefirieran guardar una cuidada distancia frente a las turbas religiosas, y a la vez desearan disociarse de todo proyecto que resultara en una igualación con sectores sociales 'inferiores' que acogieran las ideas liberales.

Desde el catolicismo se reivindicó las misiones de Ocopa como un logro histórico, y se lamentaba "el torrente de malas ideas" que habría inspirado este incendio en un afán de combatir la autoridad católica. ${ }^{127}$ La respuesta de los librepensadores fue examinar la acción de los misioneros muy críticamente en una serie de artículos. ${ }^{128}$ Por su parte, las autoridades gubernamentales se abocaron a detener a presuntos incendiarios (tres hombres y cuatro mujeres) e informaron que el "pueblo amotinado" había apresado a Chávez, a Teodoro Gamarra y uno más no identificado. El subprefecto Villavicencio comunicó que a duras penas había conseguido contener la exaltación violenta del pueblo de Jauja, la cual le había hecho temer que se lanzarían a "una invasión de Huancayo". ${ }^{129}$ Otro relato proviene del alcalde de Jauja, Reynaldo Piana, quien dijo que el 31 de julio de 1900 una turba de mujeres seguida por muchachos habría irrumpido en las casas de Chávez y Teodoro Gamarra. Al no encontrarlos, suscribieron un acta ("siendo excedente el número de mujeres al de hombres"), y se dirigieron después a la cárcel del pueblo a buscarlos con fines violentos; para impedir que lograran su cometido se formó una guardia urbana integrada por concejales y

126 Huancaínos, “Los incendios de Ocopa”: EC, 1 de agosto de 1900, p. 3.

127 José A. de la Puente, "Historia nacional. Santa Rosa de Ocopa. Misiones, iglesia y convento. A los reverendos padres descalzos": EC, 5 de julio de 1900 (mañana), pp. 2-3.

128 El Libre Pensamiento inició una serie de catorce artículos titulada "Obra de la propagación de la fe en el oriente del Perú” que se inició en el no 216, 11 de junio de 1901 y terminó en el no 316, 14 de junio de 1902, en que lógicamente criticaba las misiones promovidas por Propaganda Fide y la postura del Estado peruano de admitirlas.

${ }^{129}$ Estas versiones se adjuntan al oficio del 2 de agosto de 1900, Archivo General de la Nación [AGN], Prefecturas, Junín, paquete 67. 
comerciantes, así como por elementos de la Guardia Civil que lograron calmar la situación. Posteriormente las personas implicadas en la asonada dirigieron una carta fechada el 24 de agosto de 1900 al prefecto del departamento, Manuel J. Diez Canseco, que luego fue remitida al Ministerio de Gobierno, en que criticaban al alcalde Piana, por menospreciar el sentimiento religioso.130 Todo esto tuvo lugar en el contexto de nuevas elecciones municipales que debían realizarse los primeros días de diciembre de 1900, de manera que los sectores proclericales no podían perder esta ocasión para presionar y conservar su poder.

En el campo judicial fueron encausados Chávez, Teodoro Gamarra y Abel J. Vega, todos miembros de la delegación de la Liga en Huancayo. El proceso se prolongó hasta 1903; todo ese tiempo Chávez quedó detenido en la cárcel, hecho que fue denunciado por la Liga de Librepensadores del Perú continuamente. ${ }^{131}$ Se publicaron noticias de manifestaciones a favor de los librepensadores: los artesanos de Huancayo quemaron en efigie al juez Velazco; ${ }^{132}$ Vega fue objeto de agasajos y celebraciones en Jauja. ${ }^{133}$ El caso tuvo repercusiones inmediatas entre los librepensadores asociados en la Liga, para quienes se trataba de una cuestión social que podía llegar a tener visos políticos. Consideraban que el incendio se debía al conflicto entre un lego del convento y un "chuncho" (persona de alguna etnía local), y que esto había sido aprovechado por los sectores clericales para arremeter contra los avances del librepensamiento en la localidad. ${ }^{134}$ Censuraron el papel parcializado del juez Velazco ya que había proclamado su

130 Ibid.

131 “Chávez Patiño": ELP, no 352, 21 de febrero de 1903, p. 2; “Crónica”: ELP, no 355, 14 de marzo de 1903, p. 2; Carlos del Barzo, “Cuestión Ocopa ¿dónde estamos?”: ELP, no 360, 18 de abril de 1903, p. 3.

132 “Crónica. No todo ha de ser tinieblas”: ELP, no 363, 9 de mayo de 1903, p. 3.

133 Fray Velasco, "Huancayo": ELP, no 367, 6 de junio de 1903, p. 3. En el caso de Vega se señala que la mayoría de asistentes fueron jóvenes limeños "distinguidos". 134 El caso se fue complicando, pues dos guardias civiles declararon que habían encontrado a fray Alonso M. Velarde en la sacristía cuando acudieron al lugar del incendio, pero luego se retractaron. En enero de 1901 un sargento apellidado Huanqui intentó liberar a los presos, pero se produjo un tiroteo con el resto de la tropa, y Huanqui resultó muerto y hubo otros heridos, AGN, Prefecturas, Junín, Paquete 67: Expedientes remitido al Director de Gobierno, Tarma, 9 de noviembre de 1901. 
enemistad personal contra Chávez Patiño, a más de pertenecer a instituciones católicas. ${ }^{135}$ El periódico librepensador hizo una campaña continua denunciando los manejos equívocos de las instancias judiciales en favor del bando clerical. ${ }^{136}$ De resultas de estos cuestionamientos Velazco debió dejar la causa, pero la encargó a un juez afín que, a raíz de la agitación local a favor de los librepensadores huancaínos, ordenó que la correspondencia con Jauja y Huancayo de Christian Dam, presidente de la Liga de Libre Pensamiento, fuera interceptada y abierta. ${ }^{137}$ Dam a su vez planteó querella ante la Corte Suprema por violación de correspondencia, y obtuvo un dictamen favorable por no haber en el código penal disposición que autorizara la interceptación y apertura de correspondencia como medio de investigación. ${ }^{138}$ El dictamen del fiscal Cavero fue favorable a Chávez Patiño, quien, finalmente, el 18 de junio de 1903 fue puesto en libertad. ${ }^{139}$ En su homenaje, y a manera de ejemplo para los librepensadores, se publicó su retrato y un relato documentado del proceso y del dictamen fiscal que permitió su excarcelación. ${ }^{140}$

\section{Reflexiones finales}

En la historiografía peruana existe un consenso implícito sobre la catolicidad del país, en que se admite manifestaciones de la religiosidad popular cuyo grado de 'paganismo' usualmente se enmarca como rezagos o recreaciones de creencias ancestrales andinas. Este punto de vista suele pasar por alto las expresiones irreligiosas de una serie de personas, que son consideradas irrelevantes incluso desde el punto de

135 “Un juez imposible": ELP, no 224, 8 de setiembre de 1900, pp. 1-2.

136 Carlos del Barzo, “Ocopa ¡Alerta!”: ELP, no 228, 6 de octubre de 1900, p. 2; Simón Chaux, "Protestamos": ELP, no 234, 17 de noviembre de 1900, p. 2; "Los frailes franciscanos de Ocopa juzgados por la prensa extranjera": ELP, no 287,23 de noviembre de 1901, p. 1; Sardinas, "El colegio de los Sagrados Corazones de Ocopa": ELP, no 288, 30 de noviembre de 1901, p. 3.

137 Christian Dam / Alberto Químper, "Nuestra actitud": ELP, no 226, 22 de setiembre de 1900, pp. 2-3.

138 "La querella del doctor Dam": ELP, no 233, 10 de noviembre de 1900, p. 1.

139 "Jauja": ELP, no 361, 25 de abril de 1903, p. 3 (sobre la vista del Dr. Cavero, favorable a Chávez); "Chávez Patiño": ELP, no 369, 20 de junio de 1903, p. 1.

140 Rafael A. Mera, "Proceso judicial sobre los incendios de la iglesia de Santa Rosa de Ocopa": ELP, no 396, 26 de diciembre de 1903, pp. 1-2. 
vista de la historia de las ideas. Así, por ejemplo, al abordar a un pensador declaradamente antirreligioso como Manuel González Prada, este aparece como un caso excepcional y raro, lo cual genera un vacío interpretativo, pues aísla sus manifestaciones del contexto social e ideológico. La continuidad de la labor de la Liga de Librepensadores sugiere otro panorama (1898-1904). Por ello es interesante recuperar la indicación de Augusto Salazar Bondy que señala a fines del siglo XIX una crisis histórica del catolicismo peruano, ${ }^{141}$ la cual probablemente se prolongó hasta inicios del siglo XX, como marco para entender la emergencia de la disidencia religiosa organizada y la energía invertida en lograr la tolerancia.

La lucha por la tolerancia religiosa se apoyó en instituciones de diverso carácter: por un lado, la Gran Logia del Perú, con membresía de iniciados, y por otro la Liga de Librepensadores del Perú, de asociación libre. Ambas tuvieron un alcance nacional, no limitado a la capital, y además una perspectiva cosmopolita de sus luchas. Abrieron espacios para una gama de reflexiones y cuestionamientos que se situaron en el medio urbano, fuera este capitalino o provincial. Efectivamente, algunos individuos y sectores sociales de las provincias pudieron insertar estas ideas en los reclamos locales de mayor libertad religiosa e igualdad civil. En este punto, sin embargo, es posible pensar que el afán librepensador de hacer de la ciencia el elemento predominante que contrarrestara el influjo del catolicismo en la vida pública, no tuvo el resultado esperado. Además, si bien sectores minoritarios manifestaron su distancia frente las religiones organizadas, la puerta quedó abierta para la expansión de iglesias evangélicas y teologías heterodoxas, con lo que el proyecto de una sociedad en que la ciencia tuviera un papel público más importante quedó bastante relativizado.

\footnotetext{
141 Augusto Salazar Bondy, Historia de las ideas en el Perú, Lima: F. Moncloa Editores, 1967, vol. 1, pp. 22-23, sin embargo, Salazar afirma que González Prada profesó el escepticismo y la duda antes que un ateísmo definido.
} 